Florida International University FIU Digital Commons

6-10-2011

\title{
Shi'a women's participatory roles in the establishing and sustaining Shi'a religious identity in South Florida : Islamic Jaffaria Association
}

Ivanessa Maria Arostegui

Florida International University

DOI: $10.25148 /$ etd.FI14032348

Follow this and additional works at: https://digitalcommons.fiu.edu/etd

Part of the Religion Commons

\section{Recommended Citation}

Arostegui, Ivanessa Maria, "Shi'a women's participatory roles in the establishing and sustaining Shi'a religious identity in South Florida : Islamic Jaffaria Association" (2011). FIU Electronic Theses and Dissertations. 1314.

https://digitalcommons.fiu.edu/etd/1314 
FLORIDA INTERNATIONAL UNIVERSITY

Miami, Florida

SHI A WOMEN'S PARTICIPATORY ROLES IN THE ESTABLISHING AND

SUSTAINING OF SHI A RELIGIOUS IDENTITY IN SOUTH FLORIDA: ISLAMIC

JAFFARIA ASSOCIATION

A thesis submitted in partial fulfillment of the

requirements for the degree of

MASTER OF ARTS

in

RELIGIOUS STUDIES

by

Ivanessa Maria Arostegui 
To: Dean Kenneth Furton

College of Arts and Sciences

This thesis, written by Ivanessa Maria Arostegui, and entitled Shi'a Women's Participatory Roles in the Establishing and Sustaining of Shi'a Religious Identity in South Florida: Islamic Jaffaria Association, having been approved in respect to style and intellectual content, is referred to you for judgment.

We have read this thesis and recommend that it be approved.

Erik Larson
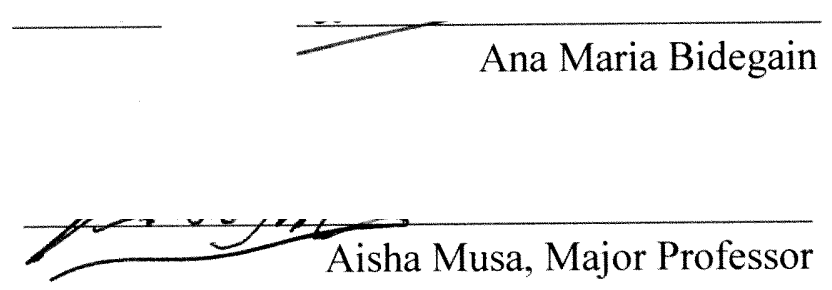

Date of Defense: June 10, 2011

The thesis of Ivanessa Maria Arostegui is approved.

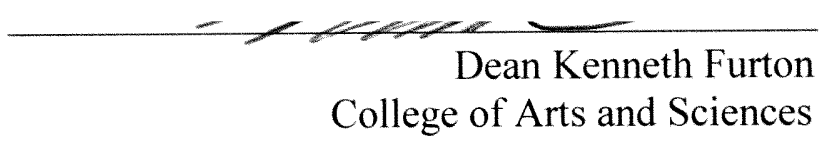

Interim Dean Kevin O'Shea

University Graduate School

Florida International University, 2011 


\section{ABSTRACT OF THE THESIS \\ SHI'A WOMEN'S PARTICIPATORY ROLES IN THE ESTABLISHING AND \\ SUSTAINING OF SHI'A RELIGIOUS IDENTITY IN SOUTH FLORIDA: ISLAMIC \\ JAFFARIA ASSOCIATION \\ by \\ Ivanessa Maria Arostegui}

Florida International University, 2011

Miami, Florida

Professor Aisha Musa, Major Professor

The research on the Muslim American community is largely Sunni

specific and the purpose of this thesis is to add upon the limited scholarly work concerning the Shi'a Muslim American community. This study looks into the American Shi a Muslim education experience at the Islamic Jaffaria Education Center (IJEC) and how it establishes and sustains a Pakistani Shi ite Muslim identity. In addition, research on widespread American Muslim education shows high female participation on all levels, including, but not limited to, board and teaching positions. To see if this situation exists inside the Shi' ite communities an ethnographic study was conducted over the course of about 4 months at the IJEC. The findings show that there is also high female participation at that Shi ite education center on all levels. The study links the high female participation with the education and how it established and is currently sustaining a Pakistani Shi ite Muslim American identity in South Florida. 


\section{TABLE OF CONTENTS}

CHAPTER

PAGE

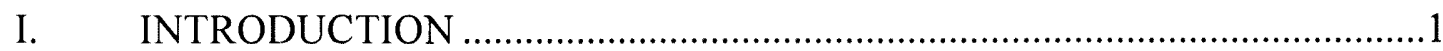

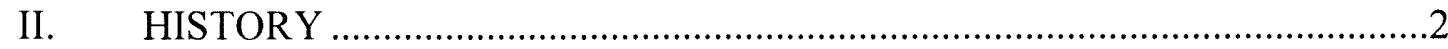

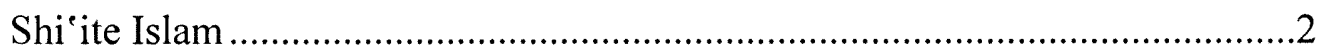

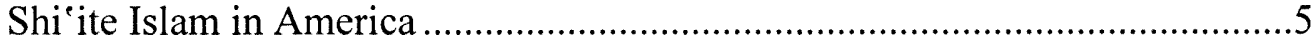

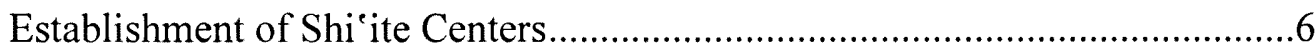

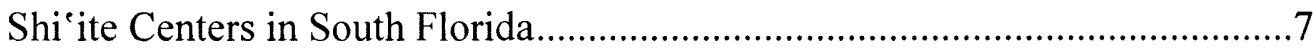

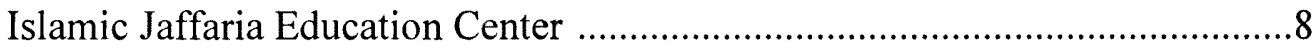

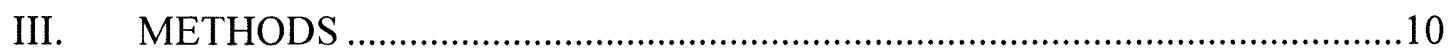

IV. THE MULTILAYERED SHI ITE IDENTITY ............................

Shi' ite Identity in an American Landscape ...............................................15

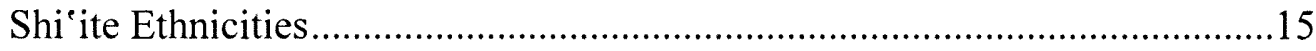

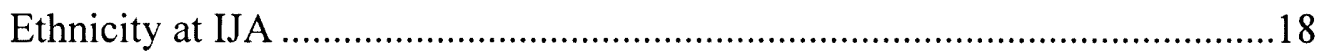

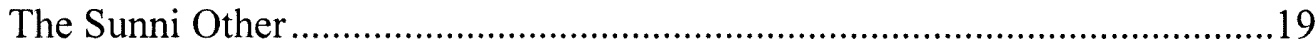

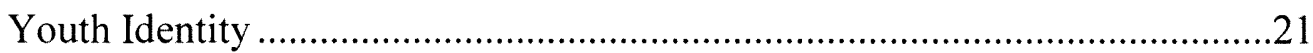

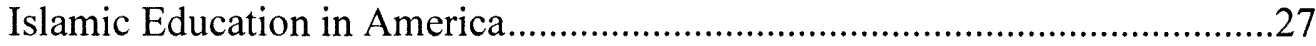

Muslim Women as Educators in America .....................................................29

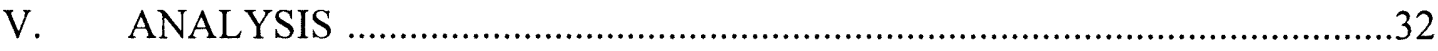

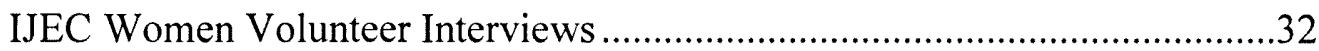

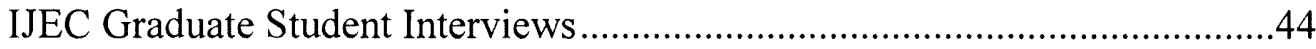

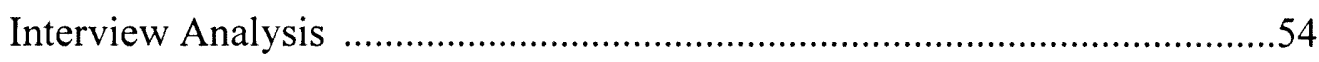

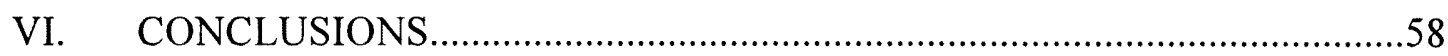

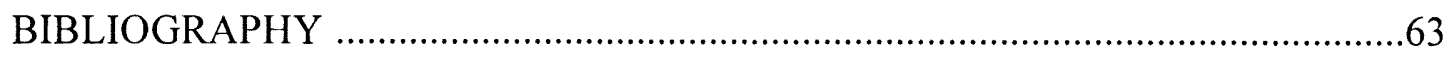

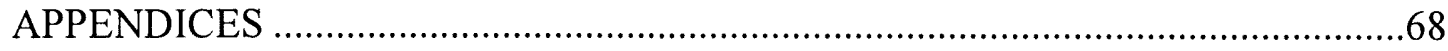




\section{CHAPTER I: INTRODUCTION}

The Islamic Jaffaria Association (IJA) is a predominantly Pakistani Shi ite community center located in Hialeah Gardens, South Florida. It was founded in 1991 and served to fill the complete absence of Shi ite spaces of worship in the region. It was the first Shi 'ite center in South Florida and seems to have flourished over the years. The presence of the Shi ite community in the context of America is significant as the community is a minority within a minority. Islam itself is a minority in the American religious landscape and in Islam, Sunnis are in the majority. Shi'a Islam is therefore doubly a minority and has had to face the struggles of establishing and developing spaces of worship. These spaces serve to maintain a Shi ite identity and understanding of Islam in the face of the Sunni majority, American culture, and even the particularities of ethnically influenced Shi ite practices and rituals. In the case of IJA, a space where a particular Shi ite Pakistani understanding of Islam is being developed, women's active participation at the center instills and sustains a Pakistani American Shi'ite identity, both for the community as a whole, and through their educational work, especially for the youth.

According to Liyakat Takim, the story of America's Shi' ite Muslims had remained largely untold. To fill in this scholarly lacuna, his study entitled Shi 'ism in America, published in 2009, contains data, surveys, and interviews he procured with various members of the American Shi ite community. It stands as the only comprehensive study on American Shi'ism. My research intends to add to his by focusing on how the Shi ite identity is being sustained by Pakistani Shi ite women in South 
Florida. This work intends to be a small ethnographic study derived from an account of the experiences of, and reports by, the women and graduates that partake in the Islamic Jaffaria Education Center (IJEC). All interviews will remain anonymous, as this is a small identifiable community. This study will also highlight the struggles of sustaining the Shi ite identity in the context of the predominant American culture, the Sunni majority, and the diversity of the ethnically affiliated Shi ite spaces. I propose that woman's participatory roles as board members and teachers, on a voluntary basis, at the IJEC is a major factor in sustaining the Pakistani Shi' ite identity in South Florida. I suggest that women's participatory roles as religious educators for the youth inside the American Muslim community be explored on a larger scale as a major contribution to understanding the Islamic identity being developed in America.

\section{CHAPTER II: HISTORY}

\section{Shi' ite Islam}

The Islamic community is sometimes mythically believed to have been split into the Sunnis and the Shi ites right after the death of the Prophet. Historically, the more official separation can be more properly dated to several decades after the death of the Prophet Muhammad. The Arabic word shi 'a simply means 'party', and became most popular in regards to the 'Shi 'at 'Ali', meaning 'Ali's party' (Halm, Shi 'ism 1). This was the name given to those who favored the succession of the Prophet's cousin 'Ali ibn Abi Talib following the murder of the third Caliph 'Uthman in 35 A.H./656 C.E. (Halm, Shi'ism 1). 'Ali at that time was the almost sixty year old husband of the Prophet's daughter Fatima and father of the Prophet's two grandsons, Hassan and Hussein (Halm, 
Shi 'ism 7). It was after 'Ali's successionthat the Islamic community (umma) was more definitively split and even entered into the first civil war over the question of who was going to succeed 'Uthman as the rightful leader of the community. Today the Shi' ites recognize Ali as the only rightful Caliph and reserve for him the title of 'Commander of the Faithful' (amir al-mu'minin) (Halm, Shi 'ism9). The majority Sunni denomination regards the three previous Caliphs before "Ali as rightful leadersas well. The followers of Shi ism have always been the minority and sometimes the opposition; they have often been persecuted, despised, or oppressed throughout their history (Halm, The Shiites: A Short History viii).

The Shi ites eventually developed their owndistinctive practices and teachings that went beyond the original cause of the split. They developed their own special relationships with their authorities, the Imams, who are believed to be infallible, they have peculiarities of religious worship, their own festivals and pilgrimages, a religious ethos to suffer for the cause, and finally a type of clergy (Halm, Shi ism 1). There are several different branches of Shi ism. The one particular to this study is the larger branch, the Twelver Shi' ites. This group recognizes twelve Imams who belong to the fourteen infallibles that also include the Prophet and his daughter Fatima. The Twelver Shi' ites are also known as the Imamiyya Shi ites and sustain a distinguishing belief in the existence of the hidden twelfth Imam who will return in the future (Halm, The Shiites: A Short History 29).

Throughout Shi' ite history the massacre of Hussein, the son of 'Ali, and his forces at Karbala by the Umayyad Caliph Yazid in 680 C.E. has served as an important 
milestone. Eventually, Shi'ite theology and jurisprudence took shape in the times of the fifth and sixth Imams, Muhammad al-Baqir (d.733-37) and Ja far al-Sadiq (d.765) (Takim, 2). The Imams are seen as exemplary models, and like the Prophet, are believed to possess 'isma, the trait of immunity from sins, hence the previously mentioned title of the fourteen "infallibles" (Takim, 3). 'Ilm (divinely bestowed knowledge) is also transmitted and retained in the particular line of the Prophet's family, i.e., the ahl al-bayt (Takim, 3). It is members of the Prophet's family that make up the imamate. It was under the Qajar dynasty in Iran (1794-1925), that the 'ulama', or scholars, established their authority as the sole exponents of the law (Takim, 5). Eventually the concept of marji 'altaqlid, or imitation of the most learned jurist, developed. In modern times, these types of Shi ite scholars play influential roles in the lives and religious practices and decisions of the Shi' ite community around the world.

By contrast, in Sunni Islam there is no recognition of an imamate or clerical system that includes mullahs or ayatollahs like in Shi ite Islam. Sunnis do not celebrate the birthdays of the imams and they do not have a month of lamentations, like Muharram, for Shi' ites. Sunnis do not pray to the imams and believe you can have direct interaction with God without the need of intercession by an imam. Sunnis follow their own canonized books for prophetic traditions that include authors like Al-Bukhari and AlMuslim. Most importantly, Sunnis recognize four rightly guided Caliphs after the death of the Prophet Muhammad. 


\section{Shi ite Islam in America}

The first significant wave of Muslims arrived to America between 1875 and 1912. They came from what was then called Greater Syria and where they had lived under Ottoman rule (Takim, 12). In Kambiz Ghanea Bassiri's A History of Islam in America, his mention of Shi ite specific history is limited to a couple of paragraphs. Shi ite Muslims from Lebanon and Syria had begun arriving on American shores in the early 1900's. Takim points out howmost Islamic scholars have focused on Dearborn, Michigan as the first city in which Shi'ite's settled (12). Chicago also became an important area of settlement but Takim discovered that Michigan City, Indiana also had an early growing Shi ite community (12). This community that was made up of mostly Lebanese and Syrian merchants actually built one of the first mosques in America in 1924 (Takim, 12). According to Hussein Hussein Ayad by 1924 there were about 200 Shi ite families in Michigan City (Takim, 13).

In addition, Mohammad Jawad Chirri, an early prominent leader and mosque founder for this community, spent two years in the early 1950's in Michigan City after a dispute arose within his Detroit community. Despite this however, it is the Lebanese Shi ite community in Dearborn that has been one of the Shi ite communities most heavily researched, especially by scholars like Lynda Walbridge (Takim, 14). Today Detroit has the largest concentrated area of Arabs and Muslims, after Paris, outside the Muslim world. It was not until the 1965 Hart-Cellar Act however that the American Shi' ite population, that was primarily Arab and Levantine, was drastically altered (Takim, 21). The act more than doubled the number of Muslims in America during the following two 
decades because it aimed at repealing quotas based on national diversity within America (Takim, 21). The act reversed decades of discrimination within immigration laws (Takim, 21). It also allowed Shi ite students, factory workers, and professionals to immigrate to America with their families (Takim, 21). The majority of these new Shi ite immigrants were from the Asian subcontinent including India, Bangladesh, and Pakistan (Takim, 22). Today there is no accurate estimate as to how many Shi' ite Muslims there are in America, but according to Jane Smith, Shi ites comprise about one-fifth of the American Muslim community (Takim, 23). Finally, the American Shi ite make-up is comprised of Iraqi, Iranian, Lebanese, and South Asian Shi' ites (Takim, 24).

\section{The Establishment of Shi' ite Centers}

As the Shi ite immigrants increased in the 1960's the need for Shi 'ite centers did as well. Shi ite's from cities outside of the ones previously mentioned began to build their own centers (Takim, 52). By the 1970's and 80's many Shi' ite immigrants realized that America would be their home especially as conditions worsened in their own countries (Takim, 52). They needed centers, Sunday schools, and places for marriage, burial, and circumcision rites to be arranged (Takim, 52). According to Takim, as families dealt with representatives from school systems, social workers, and public housing officials, they soon realized they could "not afford to remain invisible in America any longer" (Takim, 52). The Shi' ite community, in fact, built "infrastructures that would protect and perpetuate the identity of its members and ensure the transmission of its teachings to the future generation" (Takim, 52). 
In this work Takim surveyed 32 Shi ite spaces across America and from his polling discovered that roughly $45.16 \%$ of them were established in the 1990 's (Appendix Table 1, 233). He believes this to suggest that most of the American Shi' ite communities are relatively young (Takim, 53). He notes that only $9 \%$ of the centers were built in the 1970's because most of the earliest Shi' ite communities met in private homes. However, as the Shi' ite ethnicities diversified through immigration, the need for centers seemed to spring forth. He noted that the names of most of the centers followed the Ja fari school of law (Takim, 81). They bear names such as Idara Ja fariyya, Ahl al-Bayt Center, al-Mahdi Center, Ja fari Islamic Center, and Karbala Center etc. (Takim, 81). By 2009 there were around 200 Shi' ite institutions in the United States and Canada (Takim, $53)$.

\section{Shi ite Centers in South Florida}

South Florida did not have any Shi ite centers until the construction of the IJA. I interviewed a husband and a wife that were founding members of IJA and are still today active board members of the IJEC. According to them the mosque began construction in 1990 and officially opened its doors in 1991. Before the center was built a few Shi ite families gathered in homes and a few others rented space for special occasions. They would engage in lectures, religious sessions, and prayers, as well as trying to run a type of Sunday school. Eventually they had the funds and support to open a mosque. For these families Hialeah seemed like the perfect location. It was central for both the Miami-Dade and Broward families. The initial struggles included: drafting a constitution, acquiring the funds for the regular financial needs of the center, and assigning board members. The 
biggest struggle however was "having committed volunteers to put in many hours and much effort to keep the center running successfully."

Furthermore, the center was named Islamic Jaffaria Association, according to the wife, because "as Shi a Muslims we are also known as followers of Jaffer" and this name was mutually decided by all. When asked about the primary goals for the center the response from the husband was clear. He believed that the members wanted the center to be a place "where all Muslims, not only Shi"as, could come and worship Allah, and preach the religion of Islam." The most rewarding aspect of founding the mosque was seeing that their hard work had paid off. They are now able to have a space where their future generations can learn about Islam and continue to cultivate a community that is like a "family." According to the couple, since the foundation of the center, it has little interaction with other centers unless it has been necessary. They also referred to the center as an "individual/private" center. Since the construction of the IJA, two other Shi ite centers have been built in South Florida. One is in South Miami and is predominantly Iranian, and the other in Boca Raton and predominantly Arab.

\section{Islamic Jaffaria Education Center (IJEC)}

The Islamic Jaffaria Association (IJA) in general has approximately 350 members. It also has two functioning boards, the general board and the board of the IJEC. About eighty-five percent of the members on the general board have been involved with the IJA since the foundation of the mosque. About forty percent of the educational board members for the IJEC have been participating since the foundation of the education center in 1991. The education center consists of 65 students and about 25 volunteers, 
including administrators and teachers, all on a volunteer basis. Actual positions include but are not limited to: chairman to the general board, subject coordinators, principal, secretary, treasurer, teachers, and assistants to teachers. The center holds a pre- $\mathrm{K}$ through tenth grade curriculum over a thirty-eight to thirty-nine week schedule. The classes are taught as three-hour long intensive courses during the weekend.It is after the completion of 12 levels of Qur'anic subjects and 12 grades of religious subjects that a student with a passing grade of ' $\mathrm{C}$ ' or better in their final year will graduate the school. The IJA is transformed on Sundays. The space is divided and partitioned into the IJEC. There are essentially little partitions that separate small classes for the children.

The goals of the center include: building the community, training future teachers, and most importantly "to provide religious education to the child according to the Shi'a IthnaAshari school of thought" (ijamiami.org). The curriculum is focused on the following four subject areas: Qur'anic recitation and Arabic, Islamic laws and ethics, Islamic history, and Islamic general knowledge (ijamiami.org). The aim is that the students understand and be able to live "the Islamic way of life" (ijamiami.org). Their historical teachings include the history of the Prophet as well as of the ahl al-bayt and their famous Ulama. In the curriculum, the students are taught about the "panjetan." Panjetan is a word in Urdu and therefore has a specific tie to cultural understanding. The Panjetan are the Prophet Muhammad, 'Ali, Fatima, Hussein and Hassan. Outside of what is taught in the curriculum the children are taught about the taboot (mock coffin representing the sacrifices of the imams), the dharih room (the room with the flags, hands, and small representations of the shrines for the imams), and special prayers in Urdu for celebrations and lamentations. These special teachings are culturally influenced 
and are not taught in Shi ite spaces that are not Pakistani or Indian. The strong culturally influenced teaching could be resulting from a resistance to assimilate to American culture. Therefore, preserving the cultural traditions alongside the religious understanding becomes a priority in this struggle against assimilation.

\section{CHAPTER III: METHODS}

My main methodological approach involves the naturalist ethnographic framework for most of the interviews and research done at IJA and in this study. This research will be legitimized inside of social identity theory, intercultural feminist criticism, and the theory of dialogical truth. The approach is meant to utilize and add upon Takim's recent and only comprehensive study on the Shi'a community in America.

To begin with, once a group is formed its initial focus is establishing its identity. Social identity theory believes this endeavor is important because "one of the most crucial elements in the history and development of a social group is the maintenance of its identity" (Nyang, 237). The establishment of social identity involves efforts directed at defining boundaries, such as its place in relation to other groups (Worchel, 59). These groups establish a dress code or special languages and symbols to mark them apart as a recognizable group (Worchel, 59). There are even efforts made to reach back into history and establish the legitimacy of the group (Worchel, 59). Often with ethnic groups who try to re-establish themselves, cries are even made about the resources that were once taken from them (Worchel, 59). This identity establishment is apparent in the Islamic educational efforts at the IJEC. The Shi ite education immediately defines their relationship alongside the Sunni majority. Whereas many Sunnis might be oblivious to Shi'ite beliefs or practices, Shi'ite education delineates the differences with the Sunni 
majority practices and beliefs. The Pakistani Shi ite education includes special Urdu phrases that represent religious terms as well as special religious symbols and practices

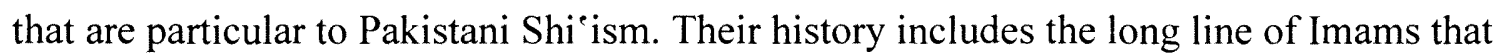
traces back to the Prophet Mohammad and therefore gives them legitimacy. Finally, their education is also full of narratives of martyrdom and what was unjustly taken from them.

Secondly, the challenge of building and defending institutions is integral when understanding social identity theory (Nyang, 239). For some scholars the task of institution-building grew out of the concern for self-preservation and a quest for cultural and religious continuity (Nyang, 242). For Muslims the religious institution is done in the "hope to remain Muslim" and the will to reconcile a Muslim identity in America (Nyang, 242). The question underlying this whole research is what and whose Muslim identity per se. Some scholars believe that Sunnis have tried to avoid the issues of "dissensions" amongst Muslims in hopes to prove to their host countries that there is only one Islamic community who identity with the majority in Sunni Islam (Sachedine, 3 ). It is also interesting to note that although a Shi' ite presence has been around in America since the early 1900's most of the scholarly and academic research has been mostly Sunni specific. Therefore, in a nation where the term Muslim is by and large defined by Sunni Islam, Shi ite institutions seem to have tougher challenge in the building and defending of their religious centers or institutions.

In addition, this research is also located inside feminist intercultural theological frameworks. One very big feminist intercultural criticism has been the exclusion of women from the spheres of knowledge production. Feminist intercultural criticism claims that any given subordinate culture should be considered to have a valid model for 
producing and reproducing wisdom and it analyzes how women within that marginalized culture have been officially left out in the process of this production of wisdom (Cespedes, 30).

If wisdom is acquired through experience and through a process of reflection on life and events, then women should in no way be excluded from the process of acquiring and producing wisdom. Rather, it is more obvious nowadays that women should be positively included in the process of production of knowledge. We should keep in mind that, according to most definitions of wisdom, knowledge is a fundamental dimension and an integrating part of wisdom, although it does not exhaust its meaning. From this starting point, then, we have the right to speak of the egalitarian inclusion of women in the process of production and reproduction of wisdom (Cespedes, 33).

In fact, women's experiences are becoming a source of wisdom that nourishes the theological and scholarly activity of feminists (Cespedes, 37). In addition, women's experiences have become a widely studied category among feminist scholars, including: Elizabeth Schussler Fiorenza, Maria Pilar Aquino, Rosemary Radford Ruether, and Elizabeth Johnson (Cespedes, 37). It is for all these reasons that the experiences by the Pakistani Shi'ite women of South Florida serve as a legitimate source of study in knowledge production. The knowledge production explored in this research includes the understanding of the American Shi' ite Muslim identity as affected by Pakistani American Shi' ite Islamic education and how women participate in this process.

The last framework this research is legitimized through is Mikhail Bakhtin's theory of dialogical truth. Bakhtin believed there were two types of truths, monological and dialogical. A monological truth is presented as a single voice (Beal and Deal, 35). It stands without contradiction or counter-voices, as if it was a finalized word on a particular subject (Beal and Deal, 35). A dialogical truth is a truth that results from 
several unmerged voices and manifests a "plurality of consciousness" (Beal and Deal, 35). This research attempts to represent a dialogical truth on many fronts. The first is to correct the monological truth of the American Muslim as found in scholarly work as being mostly Sunni based. Secondly, this research intends to include the voices of several women volunteers and student graduates from the IJEC. In fact, this research is primarily based on the voices of women and graduates by trying to understand how a double minority's identity is sustained in the pluralistic landscape of America.

To become exposed to this world and their challenges I engaged in my main methodological endeavor, an ethnographic study of a Pakistani Shi ite community in South Florida. I visited their center over the course of four months as a participant observer and conducted several interviews in the last few weeks. I embarked in a naturalist approach to the study that aims in immersion and qualitative methods of data collection. The naturalist school of thought proposes that the social world should be studied in its natural state and that research should be carried out in a way that is sensitive to the setting (Atkinson and Hammersley, 6). The naturalist framework does not engage in quantitative data collections that deal with numbers and polling. When I initially visited the mosque, I just observed and took in as much of the experience as possible. I wanted the members to get to know me and feel comfortable with my presence and research efforts before conducting any of the informal interviews. I simply focused on observing the lived religious experience of the women members and students at IJEC. On occasion, I also attended special celebrations such as Hussein Day and socialized when appropriate. 
Furthermore, gaining access to the field was not a challenge. I had been friends with a young woman who had attended IJA all of her life. She was the one who first took me to the center and initially introduced me to the other women there. In a sense she functioned as a type of "gatekeeper" especially for the first month. A gate keeper is a person who often serves as a main negotiator between a researcher and a smaller or more secluded community. Sometimes gatekeepers try to control the researcher, as they are concerned about how the researcher will paint the community (Atkinson and Hammersley, 66). In my case, my friend, that had known me for years did not try to control any of the research or the interviewing process. As the weeks progressed I slowly began getting to know the rest of the women on my own terms. These women were board members and teachers, some of them were even graduates who turned into volunteer teachers. All of these women were serving at the IJEC on a voluntary basis and most had full time jobs or college courses during the weekdays. They were also mostly not certified K-12 teachers.

Moreover, the women were all relatively easy to speak with and well educated. They especially became comfortable with me as my months of attendance progressed. Unfortunately many did not want to be part of this study. I could not use many of the interviews conducted because of the resulting material and discussion about the Sunni other. This was by far one of the biggest challenges as well as a limitation when conducting an ethnographic study. Gaining rapport with the graduates also resulted in a great challenge. I did not see the graduates at the Sunday school as they had already graduated. I met and established some rapport with the graduates in other functions, during specific celebrations, the ones for the Imams for example. Generally however the 
biggest challenge was being able to interview people that actually wanted to be part of a research project. Naturally many people were skeptical as to my research intentions and what I was trying to prove or not prove. Religion is an issue that is deeply personal and most people preferred to remain private about their feelings and experiences especially with perceived outsiders.

\section{CHAPTER IV: THE MULTILAYERED SHI'ITE IDENTITY}

\section{Shi'ite Identity in an American Landscape}

According to Takim Shi ite identity in America is being challenged by three distinct factors. There is essentially the challenge of a multiethnic Shi 'ism found inside a pluralistic America and its impact on the community, as well as the predominance of Islam being "defined primarily by Sunnism" (Takim, 54). What emerges inside this identity is thus two-fold, an ethnic and Shi ite identity. The identity is differentiated from among these: non-Muslims and/or Western secular values, fellow Shi' ites of different ethnicities, and the Sunni other.

\section{Shi'ite Ethnicities}

American Shi ite immigrants tend to re-create and live out their distinct cultures and in turn tend to divide themselves along ethnic lines. In the case of IJA for example there is a strong population of Pakistani and Indian members. "Ethnicity, broadly defined, refers to a social identification based on a set of shared cultural characteristics and a sense, on a group level, of being distinct from other cultural groupings" (Takim, 56). A Shi ite center that is re-creating a distinct ethnicity will have marked differences from other Shi' ite centers in many respects. For example, they might hold lectures in a native language, have behavioral and dress codes that reflect cultural norms and the like. The 
recreation of ethnic identity in Shi ite centershelps the communities "militate against the assimilation to the pervasive influence of American culture" (Takim, 57). They are reproducing spaces where their native cultures can thrive and somehow be passed on to their children.

However, these strong ties can create buffers within the American Shi ite communities. If the lectures or programs are held in particular languages that reflect their native countries it can alienate other Shi ites from different cultural backgrounds. In fact, Takim points out that "to date, there is no institution that can act as a unifying factor for all the diverse Shi' ite groups" (Takim, 59). These divisions within the Shi 'ite communities make having a centralized authority very difficult, and in turn, there is no such thing as a monolithic American Shi ite identity. It is fascinating to realize that in all of Shi ite history "the great variety of national, ethnic, and cultural backgrounds of Shi ites living in a non-Muslim country is unprecedented" (Takim, 59). These issues of identity are unique in this American Shi ite community due to the pluralistic American landscape. In their native countrieshowever,there usually existed one monolithic identity of Shi ism.

In addition, these ethnic ties take on one more level of dimension within American Shi' ite communities. As previously mentioned, Shi ites have various festivals and celebrations that are uniquely part of the Shi' ite Islamic experience. They commemorate and sometimes act out important historical events that the Sunnis do not commemorate. They have specially marked calendar days where they hold special holidays in remembrance of their Imams. For example, there are special functions to commemorate the martyrdom of Hussein, the grandson of the Prophet, the birth and death 
of other Imams, and eid al-Ghadir, where the Prophet is reported to have designated 'Ali as his successor (Takim, 60). Specifically, Eid al-Ghadir commemorates the day thaton returning to Medina from his farewell Pilgrimage in Mecca the Prophet stopped to rest at Ghadir-al Khumm. It is here that the Prophet was reported to have taken 'Aliand reportedly said "Everyone whose patron I am also has "Ali as a patron" (Halm, Shi'ism 7). All these commemorations are accompanied by religious rituals and these religious rituals are understood and practiced within the framework of each particular culture. Therefore, the rituals and styles of lamentations for the occasions will differ according to individual cultures.

The religious and cultural connection is important in understanding why Shi ite religious rituals will take shape and be practiced differently throughout the different ethnically tied Shi' ite spaces. "Religion is linked to culture, for the structures and practices as well as the rituals of any religious community are affected by the cultural markings of its members" (Takim, 61). Therefore, for the Shi ite immigrants, their understanding of Shi ismis seen through their own cultural lenses. It then could be the case that for a particular Shi'ite practicing Shi' ism in a different way, than that which they wereculturally taught, could be seen as an "aberration" (Takim, 62). Ultimately, these differences are marked throughout the centers in the way programs are held, symbols are displayed, rituals are re-enacted, and even how marriages are conducted (Takim, 62). 


\section{Ethnicity at IJA}

Most of the women volunteers, as board members and teachers at the IJEC, felt that the Pakistani and Indian culture influenced the IJA. One of them, who has been a part of the center for 19 years said:

We have a majority of Indians and Pakistani families in the community. Therefore it is quite natural to have our events be more focused on these two groups. The poetry, the long lectures, etc., in the language of Urdu are all very cultural. But we also have lectures in English to cater to the non-Urdu and Hindi speakers.

Another volunteer, who has been a part of the center for 16 years, felt that:

There are many rituals that are purely cultural and have no real religious implications. I think the best example is our weddings. They are less and less about getting married in the traditional Muslim way and more about out doing and out shining others. The way Imam Ali (A.S.) and Bibi Fatima (A.S.) were married is no longer the model for Muslim weddings. They are now culturally bonded to Hindu weddings. If you look at a Hindu wedding and an Indo-Pak Muslim wedding, there are more similarities than disparities. The music, the jewelry and the clothes are very similar. However, Muslim weddings have the added trauma of dowry, strictly arranged marriages and situations when a divorce is warranted but is not granted due to the Indo-Pak cultural stigma.

Moreover, another volunteer that has been going to the center since she was born believes that the cultural influences are evident in: "the style of lamentation seen in Muharram and Safar. Also the red threads used for promises and safety. Even the taboot (mock coffin to remind people of the sacrifice of the imams) is only seen in Pakistani and Indian Muslims." Most of the women interviewed gave examples of how culture influences the functions and rituals at IJA. There was one volunteer, who has attended the center all of her life as well, who felt:

And far as the IJA is concerned, tradition and culture has become the only basis for disagreement. Everyone has their own idea of what should be done based on what they grew up watching. Some of the traditions in my opinion have even 
interfered, confused, or misunderstood with religious aspects. However, it still does run properly with a functioning board and constitution.

Furthermore, the decorations and symbols displayed in the Shi ite centers also differ according to the ethnic and cultural ties the center has. From my own observations I noticed that the IJA has special rooms, called dharih. Dharih rooms have replicas or symbols of Karbala (Takim, 65). In the dharih rooms at IJA there were 'alams or flags symbolizing bravery and courage that have palm-like hands at the top (Takim, 65). The room has little miniature replicas of sacred sites as well. For Takim many of the South Asian centers have decorations and symbols like these that are meant to encourage weeping and "engender a sense of commitment and devotion to the Imams" (Takim, 65). These rooms at the IJA are usually covered by a black curtain that is pulled back during certain occasions. According to Takim, South Asian Shi ites, like Pakistani Shi ites, commemorate events like the death of Hussein through these symbols and modes of expression and this is starkly different than how the Iranian and Iraqi Shi'ite's show reverence towards the Imams (Takim, 65). For Iranian and Arab Shi ites those forms of reverence and symbolic representations are foreign concepts (Takim, 65). Iranians Shi ites on the other hand sometimes display pictorial representations and paintings of the Imams, which is, in turn, usually frowned upon by South Asian Shi'ites.

\section{The Sunni Other}

When looking at the Shi ite identity versus other Islamic denominations, the religious understanding of a true Shi' ite identity comes to the forefront. The ethnic identity takes a back seat when drawing comparisons with the Sunni identity for example. In fact, Sunni mosques seem to be more ethnically diverse compared to Shi'ite ones. A 
report by the Council on American-Islamic relations (CAIR) points out these diversities. According to the report, 93 percent of all mosques were attended by more than one ethnic group (Takim, 60). Only 7 percent of mosques had only one ethnic group in attendance and 90 percent had a mixture of some South Asians, African Americans, and Arabs (Takim, 60). These same ethnicities exist throughout the various Shi ite communities meaning that the Sunni/Shi ite identity differences do not arise from ethnic differences per se. Since Sunni Islam is the form of Islam that is in the majority throughout America, it is equivalent to Islam in the minds of many. Sunni Islam is also, as previously mentioned, the sole focus of much of the scholarship concerning the American Muslim experience. A discernible Shi ite identity in turn needs to be carved out not only among the multiethnic Shi ite communities but against the Sunni other.

In the American landscape Shi ite communities are actually allowed to nurture their identity. In Sunni majority Muslim countries, like Saudi Arabia, Shi 'ite communities are at times coerced to actually practice taqiyya or precautionary dissimulation (Takim, 79). In others words denying their identity to avoid persecution. For some Sunni Muslims, Shi ite Muslims engage in forms of polytheism and are not believed to be following the true Islamic path. There are even cases where Wahhabi or Salafi verbal attacks on Shi' ite identity are completely invidious (Takim, 79). For all these factors the preservation of a uniquely Shi ite identity becomes more important. The affirmation of their particular understanding of Islam comes to the forefront as the true understanding of Islam. Not only is their understanding of true Islamic history perpetuated in the centers through the holidays and rituals, but even in the way they pray. For example, sometimes Shi ites prostrate on top of a turbah (clay-made rock). The 
centers allow for Shi ite members to pray in the manner they see as correct and at times you can find Husayniyya as a distinguishing Shi' ite religious marker. Husayniyya can contain calligraphy with Qur'anic verses as well as salutations to, or the names of, those who were killed in Karbala sewed into fabrics or drawn in art (Takim, 80). As in Sunni mosques, where you might see images of the Ka'ab in Mecca, Shi' ite centers will have them as well, but they also display images of the Shrines of the Imams in Karbala, Najaf, or Mashad.

\section{Youth Identity}

An advantage of living in the pluralistic landscape of America, as mentioned above, is the possibility of nurturing and developing a uniquely Pakistani Shi' ite identity. However, this is accompanied by a new set of problems in relation to raising the children inside the community. As a whole, Muslim parents want to keep their children insulated from what they perceive to be dangerous Western secular values (Haddad, Smith, and Moore, 14). However, in general, the Muslim-American hyphenate as a recognizable categorization has been steadily growing. Thus, immigrant Muslim parents must deal with the interaction their children are having with American values at all levels of society. According to the American Religious Identification Survey conducted in 1991 and 2001, the number of Muslims in America grew by more than 108 percent throughout that decade (Fine and Sirin, 39). Many Shi ite youth that were either born or raised here are also adopting American culture. They are gradually moving from being Pakistani Shi ites to American Shi'ites. The struggles of identity in the American landscape, can be seen in the following quote, cited by Steve Baraboza in American Jihad, related by an American Muslim youth: "We are less likely to identify with the homesick mosque 
culture and more likely to assert a very active political role for the Islamic center, and to do it as an American Muslim community- not as Egyptian, Pakistani, or Malaysian Expatriates, but as Americans" (Takim, 83).

As seen in the quote above some Muslim American youth want to perceive the Muslim community as one whole. The focus should not be on the sectarian or ethnic divisions that could potentially cause further fragmentation. In terms of the Sunni Muslim American youth this is a more attainable goal or aspiration because ethnicity does not directly affect Sunni orthopraxy as blatantly as it does for Shi' ite Islam. However, inside of Shi ism, and as previously discussed, the different ethnicities do have a distinct effect on orthopraxy, especially in rituals and celebrations. In fact, it has not been possible for Shi' ite groups to form one single community in North America (Sachedina, 7). For these groups the "problems of cultural diversity have been significant (enough) in affecting fundamental religious attitudes" to ultimately prevent unification (Sachedina, 8). Thus, within Shi ism, culture and religion are more obviously married. An Egyptian and Pakistani American Sunni Muslim youth are more likely to perform the same religious practices in the same ways, whereas Iranian and Pakistani American Shi ite Muslim youth will probably not. That is especially true for Shi ite youths during the month of Muharram or even when reciting the universal message of the Islamic creed which is not universal because it also gives way to "regionalism" among the Shi' ites (Sachedina, 8). Essentially, the universal creed can include specific sayings in different regional languages. Again, the unifying factors in these communities are national ties (Sachedina, 8). That is the reason that community centers such as IJA wish to foster and developbotha uniquely Pakistani as well asShi ite identity in America. It is also why these two elements 
are unable to be separated regarding the correct version of Shi ism according to some Pakistani Shi' ites, especially among the older generations.

According to scholars like Takim however, the differences between how the Shi ite youth view culture and how their parents view culture has caused a chasm. The immigrant parents attempt to impose a homeland culture while their children gradually adopt an American culture (Takim, 83). This imposition has resulted in the youth questioning the religious basis for practices like matam (striking of the chest), especially when done with chains, or of the dharih room (room with replicas of the Imams and shrines) and certain wedding practices (Takim, 83). However, once again, this is why the Shi ite religious identity is taught hand-in-hand with the particular culture in which it is found. The religious practices are different according to the home country where it was learned. Therefore, the culture in which Shi ism grew inside of dictates what is seen as correct orthopraxy and when divorcing the culture from the religion, some of the Shi ite youth end up questioning what their parents understand as standard religious practices. Some even go as far as questioning the religious basis for some of those practices (Takim, 83). Thus, receiving an education that is both Pakistani and Shi ite is integral to receiving the true understanding of Islam, "true" as understood by the older Pakistani Shi ites. In other words, Islam, as seen through the eyes of Pakistani Shi ites, can only be preserved in America through the preservation of this identity as infused with both culture and religion. Ultimately, this thesis proposes that women play a major role in this crucial preservation through their efforts in the IJEC.

Moreover, this Pakistani Shi' ite education is integral for Shi' ite youth in America because the youth find themselves distant from the cultural homelands of their parents. 
Experiences that their parents had in their homeland were their parents experience and not their own. The Pakistani Shi' ite education is very much felt by the Pakistani Shi' ite youth. "Pakistani youth often complain that their parents want to raise not only Shi $i$ children in America but also Pakistani ones" (Takim, 84). However, preserving the Pakistani identity alongside the Shi' ite identity is crucial for other reasons aside from the impact the culture has on religious practices. The other is that Pakistani Shi ism as an identity in and of itself is under attack in Pakistan. Since the 1990's to the present, Sunni fundamentalists in Pakistan, often funded by Saudi Arabia, have been attacking Shi'ite mourning rituals and sacred spaces (Hegland, 216). In contrast, the Iranian Shi' ite identity for example, is fostered and developed in Iran whether or not it is developed or fostered in America.

The Pakistani Shi'ite identity, on the other hand, is not necessarily developed or fostered in Pakistan. Only about $15 \%$ of the Muslim population in Pakistan is Shi ite (Zaman, 62). This population includes 12 million individuals and most of whom are centered in the Punjab province (McCloud, 46). Although the majority of these Shi' ites are Twelver Shi ites, there are other denominations including the Ismailis, the Sevener sub-sect (Ali, 38). As previously mentioned, Shi 'ites in Pakistan are often under attack. For example, many Sunni Pakistani political activists, such as Muhammad Yusuf Ludhianawi claim that Shi'ites do not fit the definition of a Muslim (Zaman, 72). For him, because Shi ite imams and rituals may involve cursing the Prophet's leading companions, this would "effectively put them outside the bounds of Islam" (Zaman, 723). The Pakistani Sunni definition of a 'Muslim' has little room for the Shi 'ites (Zaman, 73). Prominent professors of law and hadith in Pakistan will provide or affirm intellectual 
justification for viewing the Shi ites and their beliefs as threats to Islam (Zaman, 73).

Since the 1980's there has been militant Shi ite action in response to efforts by Hanafi Sunnis in trying to impose alegally bindingsectarian identity as the "true" Islamic identity of the state (Zaman, 71). Shi' ite's have their own schools, which teach from different doctrines and use different textbooks, but are fully operational inside of Pakistan (Ali, 39). In fact, an educational center even arose in the city of Multan, in large part due to monetary aid from Iran (Ali, 38). However, in 1997 this center was attacked and looted, and the cultural attaché for this educational center was even murdered (Ali, 38).

The Islam that the older generations of Pakistani Shi' ites understand, which does not separate culture and religion, the one practiced or attempted to be practiced in Pakistan, is not always the Islam experienced by the American Shi'ite youth. Some of this youth call for the separation of the "real Islam", based on a return to the core tenets, from the culturally conditioned Islam of their parents (Takim, 87). The struggle of trying to find the true face of Islam echoes the struggle that many Muslims across denominations and cultures are also dealing with in the $21^{\text {st }}$ century. Essentially what some Shi ite youth would like to develop is a type of normative Shi ism in the neutral and pluralistic landscape of America. Concepts like these are tackled at conferences sponsored by Shi ite national institutions such as Universal Muslim Association of America and the recently formed Muslim Congress (Takim, 86). The concept of unification is interesting but completely different to how Shi ism took form and developed across cultures. In fact, most scholars would argue that any religion could not in fact be divorced from the culture in which it was formed into. The fostering and development of religions like Shi ism in America is new territory. 
Primarily, the struggles between the older and newer generations reflect the core issue of Muslim identity in America. Some Muslim youth feel that they live in some sort of "in-between-like" state (Khan, 125). Sherman Jackson, a prominent African American Muslim scholar, explains the experience of Muslim Youth:

Young Muslim Americans are still trying to some extent to reconnect with an authentically felt Muslim identity and up to this point this Muslim identity is largely located 'back home...'. That will not be the case for your grandchildren... if an Islamic identity is only located in the Muslim world, all the future of Islam in America is [over]- it's over (Khan, 125).

Mr. Jackson brings up good points: How should the Muslim American identity develop? How much should be identified with culture and how much of it should be divorced from it? These questions, in the case of Shi ism, are difficult to answer. In Shi ism cultural identity is directly linked to orthopraxy, so what might happen to the identity and practice of the Twelver Shi ites in America? Could a totally new identity and practice of Twelver Shi ites in America emerge in the newer generations? Is that what the Pakistani Shi ite education at centers like the IJEC are trying to avoid?

In Takim's 2006 survey of Shi ite centersin America, the centers seemed as if they possibly had those questionsin mind. He discovered that 70 percent of the centers listed transmission of Islam to the next generation as a future challenge (Takim, 89). An equal amount of them saw procuring the necessary facilities for this transmission as much of a challenge (Takim, 89). Shi' ite centers obviously recognize the challenges that transmitting "Islam" to the youth will continue to pose in America. However, for Muslim youth like 'Ali Dajaba, a member of the Young Muslim Association, the transmission of Islam is a challenge Shi ite centers are facing todaynot because of cultural preservation that results in orthopraxy but because they fail to reach the youth on intellectual and 
spiritual levels (Takim, 90). He believes the Twelver Shi ite Imams are placed on too high of pedestal to be emulated and the majalis (assemblies) are too narrative and repetitive to provide for the intellect and the spirit of the youth (Takim, 90). According to others however, the AmericanShi' ite institutions are modeled as centers instead of traditional spaces of worship for the exact reason of attracting youth (Takim, 91). The centers could essentially run recreational activities that were more youth oriented. In addition, many centers also set up schools and curriculums to transmit a fuller deeper understanding of Islam. The successfulness of this transmission, for scholars like Abdulaziz A. Sachedina, is the driving force behind these collective efforts by the Shi ite communities. He believes that Shi' ite's are mainly concerned about passing on their legacy to future generations and their efforts in maintaining the centers are for the "preservation of their identity in an alien environment" (Sachedina, 7).

\section{Islamic Education in America}

Muslim efforts to establish Islamic schools in America in many ways reflect the efforts to provide parochial education established by other religious groups like the Catholics, Protestants, and Jews (Haddad and Smith, 7). Religious schools are by no means an American invention and have also existed in the Indian sub-continent and Arab world as parallels to public education and missionary schools (Haddad and Smith, 7). Sometimes these schools arose as a direct reaction to colonization.

It was not until 1989 that the first study of Islamic schools in America was conducted. The Islamic Society of North America (ISNA) conducted that study and noted 49 schools in existence (Haddad and Smith, 6). About three years later the number grew to 80 (Haddad and Smith, 6). Since 9/11, Islamic education in America has become 
heavily scrutinized. Some Americans have questioned whether this education might be producing radical young Muslims in the US, because since the 9/11 attacks, the word madrassa (literally meaning school) has erroneously come to be associated with the training ground for future terrorists (Haddad and Smith, 7). There is only one oldfashioned-style boarding madrassa in Buffalo, New York (Haddad and Smith, 7). Islamic American day schools cater to both Sunnis and Shi ites, in fact, there is a network of Shi ite schools located in states like California, Maryland, and Michigan (Haddad and Smith, 7). In addition Shi ites have created a very efficient weekend religious school system (Sachedina, 11). For Shi ites, these schools are regarded as second only to the weekly and annual gatherings that commemorate the Imams as a guarantee of the continuation of Islamic moral-religious education (Sachedina, 11).

Today, despite the high post-9/11 scrutiny and although most of the Islamic education efforts are on a weekend or after-school basis, there are fully functioning American Islamic schools. In fact, there are over 200 full-time Islamic and charter schools across the nation (Haddad, Smith, and Moore 130). Most of these schools have only kindergarten through the sixth or eighth grade but about a dozen also have high schools (Haddad, Smith, and Moore 130). In 2007, a study showed an estimate of between 26,000 and 35,500 Muslim American students enrolled in American Islamic schools (Keyworth, 28). When comparing this number to the conservative estimate of 850,000American Muslim children, there was only about 3-4 percent of Muslim children actually attending full-time Islamic schools (Keyworth, 28). Today the estimate would most likely be higher as Islamic schools have been slowly and steadily rising in the last few years. 
The most interesting question that some scholars note is the effect that these Islamic schools will have on the collective identity of the Muslim community in the United States (Senzai, 254). However, because there has not been a national study of Islamic schools with empirical data, the impact is yet to be examined (Senzai, 254). The lack of studies seems to be because Muslim Americans are the most recent manifestation of anintegrating religious community in America (Senzai, 265). A few ethnographic studies have been done recently however. One study entitled Identity, Acculturation, and Adjustment of High School Muslim Students in Islamic Schools in the U.S.A., by Mohammad Adnan Al-Ghorani, showed that students in Muslim schools demonstrated high levels of success in fostering Muslim identity but had a low level of acculturation in larger society, while the opposite was true among those who attended public school, who seemed to have high levels of acculturation and low Muslim identity (Senzai, 254). The levels of Pakistani Shi ite identity among graduates from IJEC is exactly what this thesis wants to explore. I propose that women play a major role in sustaining a Pakistani Shi ite identity through running and educating the children at the IJEC.

\section{Muslim Women as Educators in America}

When it comes to comprehensive studies of Muslim women in America, most of the research is again Sunni specific or based. Shi ite women, as a whole, have additional religious practices and celebrations, and a comprehensive study of Shi ite women in America is yet to be done (Haddad, Smith, and Moore 73). Because the only research on Muslim Women in America is primarily Sunni focused, it will still have to be examined and looked at as a stepping stone for further study, especially in terms of Shi ite women in America. 
The American Muslim community, by and large, recognizes the heavy burden it bears in ensuring that the children of this community are well educated. Through studies, some of which will be examined here, it is easy to see that Muslim women in America carry the largest responsibility for making sure the youth are familiar with the basics of the Qur'an and Sunnah (Prophetic traditions) (Haddad, Smith, and Moore, 130). Although men can be teachers, administrators, and authors, it is women who are at the forefront of "managing after-school programs, educational hours at the mosque (normally held on Sunday morning and called weekend school or Sunday school), and teaching in the small but growing number of Islamic schools in the country" (Haddad, Smith, and Moore, 130). The Pakistani Shi ite women at the IJEC, like the rest of the Muslim women, seem to be at the forefront in running the education center. This view is expressed by most of the women and graduates interviewed, as will be shown in the interview section of this research.

According to recent estimates about three quarters of Muslim women comprise the teaching staff of these Islamic schools in America and as most scholars would note this is only a fairly recent development in Islamic education (Haddad, Smith, and Moore, 130). In some of the most recent studies, the numbers show that 60 percent of all American Islamic schools have a teaching staff where 80 percent of the teachers are certified (Keyworth, 31). In addition, the uncertified teachers were not necessarily uneducated, many had B.A.s, M.A.s, or even Ph.D.s but simply lacked the K-12 teacher certification (Keyworth, 31). Women are also seemingly involved at all levels. They can range from serving as principals to being in charge of fundraising or even cleaning efforts (Haddad, Smith, and Moore, 130). Sometimes, however, the lack of certified teachers 
merely reflects the lack of funds to hire experienced and accredited ones (Senzai, 258). That is the microcosmic example found at the IJEC although not a full-time school, the weekend school held at the center reflects the same amount of strong active female participation at all levels.

Moreover, the general efforts in American Islamic education until recently were scattered and sometimes doomed to failure, at times many new schools were forced to close for a variety of reasons (Haddad, Smith, and Moore, 131). In light of these struggles, the non-profit Islamic Schools' League of America was founded in 1998 (Haddad, Smith, and Moore, 131). More than three quarters of the present board for the league are women and in addition half of the founders were women (www.theisla.org). Thus it seems like Muslim women in general seemto be involved in managing and organizing Islamic education in America across the board, from the league, to the administration, to the teaching staff, and finally to the daily operations that make these Islamic schools functional. This is again very reflective of the women's participation levels at the IJEC. Two women are on the general board of the IJA and serve as chairs for the IJEC. In addition, the IJEC board, including the position of principal, and the teaching staff is mostly compromised of women. These strong efforts for Islamic education should be seen as legitimate concerns for the Muslim community especially since American public schools are a formal institutionalized mode for transmitting American macroculture to children at their most impressionable years (Reminick, 25). 


\section{CHAPTER V: ANALYSIS}

\section{IJEC Women Volunteer Interviews}

The following section will examine the great amount of content obtained from the interviews taken with the women volunteers at the IJEC and in this study. Most of the interviews were done after months of attending the IJA and after the personal interaction with the women. Most of the interviews were procured through e-mail and in response to a questionnaire sent to the women. The majority of the interviewees were teachers, with the exception of the interviews with the Principal and Curriculum Coordinator of the education center. In addition, titles and names of the women will be omitted because of the nature of this community and how small and identifiable it is. The women were promised anonymity and will be identified in the interviews with pseudonyms. Perhaps the most interesting realization in these interviews is the unique way most of the women viewed rituals. Most women viewed religious rituals as being outside of Islamic education. However, rituals inside of the academic study of religion are considered an important dimension to religion as a whole.

Sandra is the first interviewee and has been volunteering at the IJEC for "a little over 19 years", essentially since the very beginning. When explaining what she does at the center she said:

I am a volunteer teacher and I have previously prepared curriculums, lesson plans for various subjects and/or grades for this education center. On a weekly basis I will prepare for the subjects I have to teach to my students and with experience I feel that I am able to teach at any grade level given that position.

When asked what she teaches and what materials she uses she responded: "I teach Islamic history, laws and ethics to teenagers. I use the books from various other Islamic 
schools and course notes online from various Islamic schools in the United Kingdom." I later inquired if the Islamic schools she borrowed notes and course material from were particularly Shi ite Islamic schools and she responded with an affirmative. For her, as well as the rest of the interviewees, Shi ite Islam is, in fact, Islam and at times there is no need to make that distinction. Sandra teaches at the IJEC because she feels that not everyone is equipped to give a proper Islamic education at home. She gave the following insight:

I began volunteering at a very early time in my life when my own children were very young. At that time I felt the need to share my determination to educate the children of our community towards the right direction. Not everyone has the time or the ability to impart this kind of religious education to their children at home. I felt that I had the time to give. As I spent this quality time at the center, I grew to love doing what I was doing, until today it gives me a sense of peace when I see that I have made a difference with one child at any given day.

Moreover, Sandra shared her thoughts on the role of the education center and American culture and identity. She believes: "Any education center is an important aspect of a community, it keeps the community together, it gives the community a sense of belonging to a place that imparts knowledge." I asked her if she thought that the youth was struggling with American culture and she believes a struggle happens when the children get involved with the wrong crowds. She explains:

If one really examines the Islamic studies, it will noted that much of it is pure common sense and it teaches patience, virtue, and most basic living skills to live in any society or culture. It is only when the youth associate with the wrong kind of people or friends that they feel the need to struggle. Majority of our youth are quite level headed and know the difference if any.

It was interesting to note that she views Islam as a way life that can teach anyone to live properly in any other culture, in the context of this research that would mean American culture. The next question was also interesting. As I attended the IJEC over the span of 
months I always saw a strong female presence and in fact the numbers alone show that women make up most of the volunteers at the center and at all levels and yet many of the older interviewees, like Sandra, were hesitant to leave the male presence out. When I asked Sandra: "Do you feel a strong female presence and participation at the education center?" she responded:

Well many of our male peers work in the background too. And if it were so, in my opinion that is a good thing. Moms find it difficult to let go of their children especially on the weekends so they want to volunteer, it keeps them busy and it is really a great help to the center.

Furthermore, when asked: "Do you feel like the Pakistani/Indian culture influences the education center? If so, in what ways?" she responded "No, not really because Islam teaches Unity and our books are quite focused on the Islamic ways of life rather than Indian or Pakistani culture or influences." However, when asked specially about rituals her answer changed. When asked: "Do you feel the Pakistani/Indian culture affects the rituals and celebrations at IJA?" she was very affirmative in her answer:

Yes, the IJA rituals and celebrations are a different story altogether. We also have a majority of Indians and Pakistani families in the community. Therefore it is quite natural to have our events be more focused on these two groups.

When trying to understand why the center was so close to her heart she explained:

Once said by our holy Prophet - peace be upon him "Seeking knowledge is obligatory upon every Muslim." This [knowledge seeking] is not just [in] any school of learning it is a place for religious education, it is also a place where we pray, meet and greet our fellow Muslims. The Education center is a place where I can give a little bit of my time and simultaneously the children give me the energy I need to feel that I belong someplace where I am needed. This is good for my heart and what is good for my heart is good for my soul.

On the other side of the spectrum is a younger volunteer teacher who has only been volunteering for only "almost two years now", and I will call her Cindy. Cindy grew 
up attending the center and after graduating she became a volunteer. When explaining what she does she said:

I am a Diniyat teacher. Diniyat is where children learn the fundamentals of Islam, the teachings of the Quraan and establish the foundation of how to be a good Muslim. In this subject are two areas: Fiqh and History. In the first half of the semester, my students are taught what are the laws and ethics in Islam. History comes second, and this is when they learn how and when Islam came about. The material comes mostly from the IJEC. They provide the course material and I often supplement it with interactive YouTube videos or stories I find on-line.

She also "generate[s] lesson plans that include in-class activities, homework and testprep, if applicable." Her decision to volunteer was motivated by her own child. She explained that she made the decision to join when her daughter turned $31 / 2$. She knew she wanted her to be a part of the IJEC, and volunteering seemed to be a natural decision for her. When discussing the role of the IJEC she clearly stated that:

The most important part of the IJEC is that it allows the students to identify with Islam, and not just the western, Anglo-culture. There needs to be a place where they can understand why being Muslim is a good thing and gain perspective on the value of not only being a Muslim by name, but through their actions, as well.

In this quote, it is clear she believes that the center instills Islamic identity to the students and is exactly what this research is arguing. When asked: "Do you think the youth is struggling with American culture and influences?" she gave a very interesting answer about how she perceives Muslim youth.

Very much so, and it is becoming a problem of epic proportions. Right now there are three groups, in my opinion. The first is very much involved in Islam; they have embraced it with open arms and are willing to exclaim it from the rooftops that they are Muslim. The second group has completely forsaken the religion and no longer follows it at all. The third group is the largest and is by far the one to watch. This section of the youth is Muslim when around Muslims, but western around school/work friends. The youth thinks they are pretty clever but they don't understand that this is a temporary fix. The decision to identify with one culture is important because when they get older, they need to know how to raise their 
children or the pattern will repeat itself. This is particularly true with first and second generation Muslims living in the US.

This final comment on the three perceived cross sections of Muslim youth is quite interesting. Cindy is implying that culture is also part of religion and that you need to identify with it so that when youth get older they would be able to pass down their traditions to their children. However, interestingly Cindy identifies as an AmericanMuslim. She explains:"I can't say I'm a Muslim American because I always identified myself as American first and learned how to be a Muslim second." When asked about the presence of women at the IJEC she said: "Just like in most education settings, women are leaders in nurturing and educating children. I think it has something to do with our higher pain threshold." Regarding the cultural influence at the IJEC, she explains:

There is some Indo-Pak influence in our education center, and yes it has to do with our culture. It is not as bad in the IJEC, though. There are some instances of hurt feelings when a child is not recognized. A parent will ask "why did my child's name not make it onto the program, or how come he got an award and my child didn't?' These are found in western education centers also, but the accusations are more forthright since it's culturally acceptable here. Teachers can also get like that sometimes, but more often than not, the volunteers we have are all dedicated to educating the children.

Finally, Cindy explains why she volunteers at the IJEC and it has a direct link with the future of her own children. She hopes that there could always be a place where they too can have a space where they can identify with Islam. She explains:

I have a daughter and God willing if I have more children, I want them to go to a place where there are people who are willing to give them answers to their questions if I am unable to. I want to make IJEC a place where Muslim children feel they can identify with $100 \%$ of the time. Every Sunday I wake up happy and excited. I don't know if that's because of the students, the material or a blessing by God, but either way I take it as an indication that the IJEC is the right fit for me. 
Monica is another volunteer at the IJEC and has been volunteering there since October 1991 and thus since the opening of the center. She explained her positions as: “...a board member, Youth Chair person, prepare by planning events with speakers and food. Sunday school principle, with the same prep weekly." She believes the IJEC is important because children are "surrounded by western culture and the IJEC becomes an important place to learn about God as well as to learn moral and ethical conduct." She believes one of the greatest challenges for the children is sometimes due particularly to the cultural influences at the center. For example, she explains: "kids just don't understand speeches in Urdu." Monica was clear about identifying herself as Muslim American and believes there is no difference between American Muslim or Muslim American. She explains that particular identification as being "a play of words. One who considers themselves as Muslim American would also defend America and the religion if it came to it." Monica also contends that the curriculum is based on Islam but is always understanding of others." She is most proud of the fact that "graduates come back to teach."

In addition, in terms of strong female participation, Monica admitted that the case for that could be made but that in the "beginning the IJEC had seen more male participation." The center for her plays an important role for the future generations. She explained "The center makes sure the next generation doesn't lose the right path of Islam. The center even teaches the differences between Sunnis and Shia's and even teaches the four schools of Sunni thought." She was very adamant about the fact that"education starts with the mother" and very proud of the all 25 volunteers and 65 kids enrolled at the 
center. Finally when asked: "If you taught at the IJEC, would you consider the time you spent in educating at the IJEC a waste if a student in the future goes to a Sunni mosque because it is closer to their home?" She replied "Never because if a former student is attending a mosque that is all it matters. It shows he is still following the religion, maybe looking for answers or trying to get a better understanding. All Muslim sects have the same basic teachings.”

Jessica, a younger volunteer, in fact another graduate turned volunteer has been volunteering at the IJEC for about 3 years as a substitute, a teacher, and an assistant. She explains her duties in the following statements: "I am a teacher for pre-k and kindergarten for foundation studies and basics. I teach about the main principles of the religion, such as religious months and days, prophets, etc." She went on to explain how the IJEC prepares teachers for that position. She explained:

To prepare for a teaching position, the IJEC has semi-annual teacher workshops as well as monthly meetings. To prepare for the class, a wide range of books and online sources are provided. Some research is done online to prepare worksheets and class activities/assignments. Exams are administered orally considering the age group of my class (4-6). Not all students are capable of reading at a fast pace.

She personally volunteers at the IJEC because she feels: "It's a great opportunity to spread knowledge to the next generation. Not only through means of religion, but moral values as well and sometimes relating both together, teaching them both through personal experiences and encounters." She believes the center is a place where the children can learn about their own religions and amongst other children that share mutual beliefs.

She explains: 
The education center seems to keep the youth grounded in a sense. It gives them the opportunity to be familiar with their religion and to meet friends that share mutual beliefs. It also gives them the ability to juggle multiple subjects and assignments at once keeping them organized and better prepared for the future (graduate level studies) considering that they go to school 6 days a week versus the typical student who goes 5 days. Students are assigned research projects, presentations, homework and exams.

Furthermore, when asked if she believed the youth was struggling with American culture she explained that it seemed to be an issue for the progressing generations because of the significance the American society places on "cultural norms" and materialism. She finds that the center is a place that can ground the youth from the wayward path of society at large. It is her understanding that:

As generations progress, the youth is somewhat drifting into more cultural norms instead of valuing their religion. In today's society, too much significance is given to materialistic things and it definitely shows in the youth today and that is why the IJEC is there, to try to keep the youth grounded.

When asked, about the presence of women at the center, Jessica explained that this presence was systematic of the widespread phenomenon of female participation on all levels of society. It is also curiously mirroring the larger picture of female Muslim participation inside of American Islamic education as a whole. She relates:

The education center has given equal opportunities to both men and women, younger and elder individuals. As more women are being educated and accepted in society today as well as the religion of Islam, I feel a strong acceptance and presence of women not only at IJEC but in the world generally.

When asked if she thought that there were Pakistani cultural influences at the IJEC, she seemed to not really believe so. She did not think the center was a place where a student should be "culturally reformed." She elaborated:

Personally, I don't feel that culture influences the education center as much as it does IJA. This is because the education center has a strict format based on lesson 
plans and rules which don't give teachers the opportunity to incorporate their culture into. Also, it functions as any school would, from attendance to exams to presentations. Besides the fact that parents send their children to a place where they are informed about religion to make proper choices in life not to be culturally 'reformed'.

However, Jessica does see Pakistani influences much more clearly in other places,

like in the IJA general board for example. For her, the general board is where people's cultural upbringing dictates the correct forms of practicing the religion. She explains:

And far as the IJA is concerned, tradition and culture has become the only basis for disagreement. Everyone has their own idea of what should be done based on what they grew up watching. Some of the traditions in my opinion have even interfered, confused, or misunderstood with religious aspects. However, it still does run properly with a functioning board and constitution.

In addition, Jessica explains how the center has impacted her life on a personal level, explaining the many levels of enrichment and deep fulfillment that has stemmed from it.

She said:

The education center is very close to my heart because I grew up there. For the past 16 years of my life, I have gone there almost every Sunday. I was taught by the best of teachers, made incredible friends, learned how to be a better person overall and I would want nothing more than to return this back to the younger generation and give them a chance to experience what I did, to gain memories to cherish for the rest of their lives, and the chance to learn the smallest of things so one day they can pass it on to their own kids.

On another note, Jessica had a few things to say about her identity. She explains:

"I consider myself to be an American Pakistani Shi a Muslim due to the fact that I was born and raised in America and follow the culture and traditions of both western and Pakistani ideas since I was raised by two Pakistani parents." She believes that:

Identifying myself as just American Muslim in my opinion is not accurate. If I am classifying myself through a regional perspective or country, than I can't just call myself American since my family background is Pakistani. That is why I consider myself an American Pakistani Shia Muslim. 
When asked if there was a difference between American Muslim and Muslim American, she replied: "For some people it might be an issue of priority such as if they feel they need to classify themselves by their religion or their culture first but for me that has no priority, I would classify myself either way." When asked if, and how, Pakistani Shi ite women develop or sustain that identity, she explained how she believed that is accomplished:

I think it's just by their actions at the IJEC and in everyday life. It's how they portray themselves because it's human nature to be stereotypical and sometimes judgmental. So as a minority in south Florida, it is important for us to let the people "watching" us see the true side of Islam and the respect that women have in the religion, rather than what is portrayed about them in the media.

For Jessica, the respect that Islam has towards women is what allows them to be so active at the IJEC. In conclusion when asked: "Would you consider the time you spent in educating at the IJEC a waste if a student in the future goes to a Sunni mosque because it is closer to their home?" Jessica replied:

Being apart of the IJEC as a former student and teacher, I was never taught to neglect other beliefs, instead was encouraged to explore and understand as well as respect for others, not only by means of religion but also cultures and ideas. Of course it is important to practice your own religion, but that does not mean you can't go to a Sunni mosque or a church. Being a Muslim and reading and understanding the Quran, I know that what the Quran teaches is not just how to religiously live your life but also how to just be a good person.

Next we have Ramona, another graduate turned volunteer for the IJEC. She functions as the Coordinator of Curriculum and explicitly said that the "curriculum was not culturally biased." In fact, she showed me the text books for grades 1-7 and they are obtained through the Shia-Muslim Association of Bay Area. These textbooks are accessible and downloadable to the public at their website http://www.saba- 
igc.org/sunday-school/sabbooks. The grade by grade curriculum for the IJEC is also accessible via the web at http://ijamiami.org/madressa_curr.html. In addition, the manual for the policies and procedures at the IJEC is downloadable at http://ijamiami.org/Policies_Procedure.pdf.

In addition the best part of the IJEC for Ramona is that "kids get together to be Muslim with each other." For her with the IJEC the kids could experience "a sense of emptiness because [the IJEC] it's a place of belonging, warm and with friends." She identifies as Muslim American and is very proud of being so. She explained that the center tries to connect with other Shi ite spaces in South Florida and they "sometimes have speakers from Ershad [the Iranian center in South Florida]." She feels "the center allows her to get to know who she is." For her the center functions "to make the community stronger." She believes that the cultural influences are seen outside of the IJEC, for example: "speeches by Imam are done in Urdu, dress and food as well as decorations and rituals are primarily Pakistani." She also believes that"sometimes the kids are at a disadvantage because they don't understand Urdu." She is very proud of the graduates who later become volunteers, like herself, and that the teachers are mostly women. For her, the school, although limited in comparison to the 5-day-a-week public school, does function like a regular school. For example she explained that "the kids are graded and they have a graduation day." Ultimately, for her the center functions to keep a "close knit community and most people are still around."

Next we have another graduate turned volunteer for the IJEC. Ana has been volunteering for almost 2 years now and only responded to a few questions. She is ".... a 
teacher and I prepare lesson plans each Sunday." Ana teaches: "Deen (Religion, including history, laws, morals, etc) and Arabic (letters and some grammar). I make worksheets or find them online. I use videos and act out situations to help them understand." When asked "Why do you personally decide to volunteer your time and dedication to the education center?" she replied,"My Sundays always mean Sunday School. It has become a part of my life that gives me meaning to it." When asked "Why is the education center important for the community?" she replied, "It helps build the future generation so they would not get lost." She does believe the youth is struggling with American culture and personally identified as American Muslim.

Michelle is the last fully interviewed volunteer that wanted to be included in the research. She also did not answer very many questions from the questionnaire although she spoke with me heavily outside of the research questions. Michelle has been volunteering at the IJEC since the beginning of it in 1991. Michelle explains that she is: "...a proud Pakistani and American at the same time. If I had to be specific about my culture and religion that is what I would consider myself." However, she would rather be identified as Pakistani American Muslim than any other identification label. When asked: "Do you think women play a role in developing the identity of Pakistani Shi'a Muslim American in South Florida? If yes, how so?" she replied:

Yes. We are active at the IJEC and attend several community events such as marathons, charities, and fundraisers and I think that lets other individuals know that we are also well informed and capable of doing these everyday things as our religion does not restrict us from doing so. 
Finally when asked: "If you taught at the IJEC, would you consider the time you spent in educating at the IJEC a waste if a student in the future goes to a Sunni mosque because it is closer to their home?" she replied:

Just educating the students and informing them about religious values and morals is enough and the fact that we spend time with such special students that become an important part of our lives is a great feeling. We can never consider our time spent as a 'waste'.

\section{IJEC Graduate Student Interviews}

The process of interviewing graduates was a little more difficult as I primarily visited the Sunday school, where they no longer attended. I had met some of them, however, during certain celebrations like Hussein Day at the education center. In addition, they were also promised anonymity and I will be using pseudonyms. In general the youth seemed to gain a lot from the center in terms of Muslim identity and were much more vocal about the strong female presence at the education center.

Megan is my first interviewee and attended the IJEC for 10 years and graduated in 2004. She feels that the center provided a lot for her. She explains: "The education I received, especially the first five years was very important. This is what allowed me to understand how to be a Muslim, and it showed me that I am someone other than just American." She commented that she felt the IJEC had "... a very strong female presence. All the years I was a student my teachers and most of the administration were women. They shaped the curriculum and helped create the atmosphere of the IJEC." Had Megan not attended the Sunday school her life would have been very different. She paints this picture: 
It would have been definitely different had I not attended. My morals would have been completely different. What I know to be wrong (i.e., drinking alcohol, eating haram, etc.) would not have the same implications attached as they do now. If Sunday school had not taught me Islam, I don't know if just my parents telling me to not do something would have worked. I love my parents, and they have worked hard to make me a Muslim, but they were not capable of answering religious questions; the IJEC filled that void. I don't think I would have identified with the IJA or with Islam without it. Not to say that all people who come to Sunday school turn out to be practicing Muslims, but more often than not, they are still around and are active ineducating the youth on Islam.

She really feels that her Islamic education would have been severely lacking had she not attended the education at the IJEC. When asked if she felt that the center truly gave her a stronger understanding of Islam she answered:

Yes. Islam clearly states the importance of education and the sin of ignorance. If one has a question regarding Islam, it becomes compulsory to answer it. Having a higher education and access to technology like the Internet puts me in a unique position where I can find answers to my Islamic questions without having to consult our resident spiritual advisor constantly.

For Megan, the center provided the educational tools for a responsible and adequate Islamic educational journey as an adult.

Moreover, Megan feels the IJEC plays an important part for the community because she feels it brings the community together. This is especially important because many of the members are immigrants who have left a lot of family back home. She explains:

I think the center has allowed us to come together continuously for the last 20 years. We consist of mostly transplants in IJA. Meaning, the first group that came to America left behind their families in Pakistan, India, Africa, etc., to start a new life in America. I am first-generation American, and so are most of my Muslim friends. We all grew up with each other, and not with cousins, nieces or nephews like most American families. Therefore this community is our extended family. When one family celebrates, we all celebrate, and when one mourns, we all cry with them. IJA is a family, and probably one of the closest I'll ever find. I know more about them than my own blood relatives! 
When asked "Do you feel the education was influenced by the Pakistani/Indian culture?" she responded:

I don't think so. When I attained my education the center was smaller and there were less cultural influences. But the center is almost double in size now so there are more opinions in the mix. I think if you ask a student who graduated maybe two years ago, he/she might say yes, but I don't think that would apply to me.

Somehow she feels as if the cultural influences at the education were present but are somehow diminishing over the years. Her best experiences from the center included being able to be with her friends. She explains:

I could only have sleepovers with my Muslim friends so I would love coming to Sunday school. I also loved the interaction we had with our teachers. Again, the classes were much smaller so we all really knew one another. It was a great time, and I to this day remember a lot of the lessons I learned from the center.

The next interviewee was Claire. She attended the IJEC since she was 3 and graduated in 2010. Claire identifies as an American Muslim and definitely notes the strong female presence at the IJEC. She explains: "[The] majority of my teachers have been females. Over the years the principles are women $75 \%$ of the time. The administrative staff is also usually women." In fact this year two women are now a part of the IJA general board as Chairs for the IJEC, positions never before held by a woman. When asked: "Do you feel your education gave you a stronger understanding of Islam?" she replied: "Yes and no. As I got older I was given the information that helps me understand information that I can read in religious books. Now I can study on my own and search for answers to which I have questions for." Then when asked: "Do you feel the education was influenced by the Pakistani/Indian culture? Claire replied "At times I do feel that, but lately the administrative staff has tried to stay away from culture which is 
not part of religion." She also explained what she enjoyed the most from her experience at the education center. She explains: "The friends I make at the education center have been my longest and closest friends. It's my extended family." Finally, when asked: "Do you feel like the Pakistani/Indian culture affects the rituals and celebrations at IJA? If so, in what ways?" she clearly responded: "Yes I do, the style of lamentation seen in Muharram and Safar. Also the red threads used for promises and safety. Even the taboot (mock coffin symbolizing the sacrifice of the imams) is only seen in Pakistani and Indian Muslims."

The next interviewee was Brenda. She attended the IJEC since 1995 and graduated in 2008. She felt the education she received at the IJEC was seminal in her understanding of Islam. She felt that the IJEC provided a space where she could learn about the "real Islam." She explains:

The education I received not only informed me of religious beliefs but also gave me an understanding of how I should live my life. Considering that the media portrays Islam to be a religion of "hate" it was often hard to have faith in something that was portrayed in such a negative manner. The teachers and superiors at the center gave me a chance to understand what the real Islam is and what the holy Quran teaches, i.e. not to be terrorists or pessimists or even more religious but rather good people. They helped me look into the deeper meaning of being a Muslim and how to see Islam as the right faith for me. I learned etiquettes and moral values that I could carry with myself for the rest of my life, whether I am a Muslim or not.

Brenda also explains how she views her identity. She was one of the few interviewees that feels the need to distinguish her Pakistani and Shi ite heritage. She explains:

If I have to classify myself it would be as an American Pakistani Shia Muslim. I was born and raised in America, with the culture and traditions of Pakistani parents and chose the sect of shia-ism and a Muslim as a whole. I do on a deeper level feel that it is not necessary for any individual to have to identify themselves 
as belonging to a group or a faith or even a gender. At the end of the day, we all are human beings, and should worry less about judging someone for what they believe or what they have by means of materialistic items. We should accept people for their individuality and the qualities they possess and accept them for it.

She commented that there was a strong female presence at the IJEC and their guidance extended far beyond the walls of the IJEC. She went on to explain:

\begin{abstract}
All the female teachers and administrators were like mothers, aunts, sisters, and even friends to me. They were there for us whenever we needed guidance or someone to just talk to. At the end of the day, that is what they volunteer their time for, not to gain a title as a principle or treasurer to name a few, but to have a positive effect and influence over any child and to help them face their problems instead of walking away from them.

Moreover Brenda believes that she would not be who she is today if not for the education she received at the center. It was especially crucial her for because she grew up in America and she felt that Islam was not depicted as a peaceful religion in the media.
\end{abstract}

She believes the center allowed her to find acceptance of herself as Muslim. Brenda said:

If I had never attended the education center, I feel that I would be a different person today. I could possibly have ended up hating a religion that truly stands for peace. I would have never learned the true meaning of modesty and respect through different people and personalities and I would have never been able to truly accept myself for who I am and what I believe.

She also added that her teachers helped her in studies during the week and in addition to the Sunday teachings. This speaks to the dedication of the teacher volunteers at the IJEC. She explained:

The education center definitely gave me more knowledge and material to learn from about Islam, even more than I would have been able to do own my own. With teachers who were willing to give up their own time not only on Sundays but throughout the week to study from books, by asking scholars and attending numerous workshops to answer questions we had. These being things I wouldn't have done on my own or maybe not even have sufficient sources to acquire the information I needed at such a young age ( apprx.13yrs old.). 
She also believes that:

The center has given the community the sense of embracing different cultures and given the importance to the youth and encouraging them to participate in activities not only related to the mosque but also the community as well, such as attending walkathons, competitions, etc.

Brenda had always attended Sunday school regularly, especially "because my parents had been active members and still are today, we rarely missed a Sunday school session." Finally, Brenda enjoyed the Sunday school because: "It was not only a place where I would go to do work but also to have fun and be able celebrate religious holidays with my friends and peers."

The next interviewee was Brad. Brad started the IJEC in 1994 and graduated in 2006. He believes the education he received at the IJEC played an instrumental role in developing his identity. He explains:

The education I received definitely led me to understand what and who I am as a person. I am the type of person that likes to look into everything and doesn't easily believe everything that I am told until I go and do my own research or ask multiple questions. It helped me compare other religious and educational information that I received throughout high school and college.

Brad identifies as a "Pakistani American Muslim", he curiously does not feel the need to distinguish his Islamic denomination. He also believes there is a strong female presence at the education center. He explains:

As students we were surrounded by females especially because of the fact that most of the females that began the center and initially volunteered their time were mothers of most of the children. Women were given much respect and the freedom to express their ideas, concerns, and views which was a good thing for students to be surrounded by since it demonstrated that it is acceptable for women to dominate. 
Brad clearly sees the women at the IJEC being able to have the freedom to maintain and run the center because of the respect the community has for these women and their ties to their children and their children's education. Ultimately, he believes his Islamic education would not have been complete without the education he received at the center. "I would have not learned a lot of the details of my religion that I did learn from teachers that research and focus on specific topics", he explained. He added: "The education I received from the center gave me a stronger idea of what Islam is based on. It also gave me a way to compare the actual beliefs of Islam to those that are taught in school."

In addition, the center for him is very important and takes on many roles in ultimately strengthening the community, he explained:

The center has not only proved to be a place of getting Islamic education but also a place to improve social skills through making friends, getting advice from teachers and superiors, and most of all was a place to have fun. All of these factors have made the community stronger as the IJEC and IJA support each other.

Brad was also very involved during his time at the IJEC; he believes it was because of his parents. He explains: "Since my parents were active members, I was there almost every weekend and was awarded perfect attendance trophies almost every year." When asked if he saw cultural influences at the IJEC he responded by saying: "The board of the education center had much cultural diversity so I don't think it was ever allowed to be a place where cultures were dominating. It was more of how to provide the students with the best education possible." The greatest part of the center for him was: "The afterschool activities with the youth groups as well as the fundraisers and picnics and competitions." He explained that he saw more cultural influences in the IJA general board. He explains: 
"Unlike the education center, the IJA definitely is influenced by culture because most of the attendees want to preach and practice Islam the way that they were brought up doing."

Specifically, in terms of identity Brad explains that he feels mostly American but is very grounded about his Pakistani roots:

I was born in Pakistan but was 6 months old when I came here so I consider myself American for the most part but I wouldn't be embarrassed if I someone asked me where I was from or if I had to correlate my culture and religion at the same time when identifying myself.

For him American Muslim or Muslim American is an issue revolving around "on what you are trying to enforce, being a Muslim or an American but I don't think there really is a difference." When discussing the possibility of fellow graduates attending a Sunni mosque he explained that: "They [a fellow graduate] should be able to explore. And if it's just a matter of them going to a Sunni mosque because it's closer to home, than that is better than the student not going to a mosque at all."

Finally, Jacob was the last graduate interviewee. He attended the IJEC all of his life and graduated in 2003. He was hesitant to answer many of the questions but he did respond on a few and was very opinionated in his responses. When asked: "If you consider yourself American Muslim or Muslim American, would the identification of Pakistani Shi'a Muslim American ever be relevant or employed, if so how, why, or in what setting ?" he gave a very lengthy response. He said that he was American, and the need to identify his beliefs was only relevant if asked. For Jacob, the Pakistani immigrant story is just like all the immigrant stories that make up America. He elaborated at length: 
We are Americans. Most children have more preference for American foods, clothing, and sports. Yes we try to keep as much identity as possible, but not to separate us from others, or to show that we are an exclusive group if chosen ones. We do it the same reasons the Irish, the Italians, and Jews did it. Simply so we are not $100 \%$ assimilated. Never forgetting who you are is as powerful for our identity as it is for the rest of our nation. It is something which plays with the minds of the rest of the Western world, and the rest of the globe. We are different peoples, yet rally under the flag as Americans. If you've ever traveled, there is no place like here [America]. We are the only true free country in the world. Because we don't have a long culturally and ethnically implicated history as other countries with long long rich histories. Even if we do have a history, it's extremely borrowing from everywhere else. It's our strength as Americans. We do not have one single history to be burdened/ashamed of. As people of different backgrounds we share all our burdens together, that sums up America. The identification can be relevant in Pakistani/Indian communities. But in the real world, it's just a mindset that comes with being Pakistani the reputation is one of a hard worker, and being studious and family oriented. And that's our culture in a nutshell. I have been told MANY tines, that employers take an extra interest in us [Pakistanis], cause there's "something extra". A benefit, yes. Makes us better? No. Just comes in handy, we identify ourselves as Americans. Muslim correlates with beliefs. American is who we are. Why separate ourselves by belief, if it's not pressing at the time. But we will let it be known if it's needed. But we don't prance or brag.

Furthermore, Jacob believes in a more concise fashion that "Islam is a way of life. We live an Islamic way of life, with American flavor." When asked if he believed there was a difference between Muslim American or American Muslim he replied that it does not make a difference except for American radicals trying to make a moot point for profit. He explains:

Nope. Tomato tomahtoh, potato potahtoh. Only idiots stress euphemisms. By the way, America-hating radicals usually go for this topic, as it is so easy to make mountains out of molehills. Why? It's good for business, causing even the slightest mischief or pain in the butt is there life. We hate them, they ruinour reputation and intentions.

When asked: "Do think women play a role in developing the identity of Pakistani Shi'a Muslim American in South Florida? If yes, how so?" he again gave another very lengthy response. His response is interesting because he tied Pakistani American Shi ite women 
to the ultimate mother figure inside of Shi ite Islam, Fatima. Fatima was the daughter of the Prophet and wife to Ali ${ }^{e}$, one of their beloved Imams and rightful successor to the Prophet. Jacob explained:

Yes! Women are central to our religion. They are central to family, community, country. And Islam is community and family. Our believed Fatima is mother to 11 imams. There is something called hadith e kisa, Shia Islam is based on that and only that. It is Fatima's story. Her father is Prophet Muhammad, her husband is Imam Ali. And she is mother to all other imams. She is the centerpiece. That's why we cherish women. Same as men in God's eyes.Just different responsibilities. Not functions, responsibilities. Meaning if they can fulfill the role of mother, they can do everything else they want. Function means you do that and that's it. Those people that are really strict and mean to women are radicals. Because a Childs education starts at home, the mother is their first teacher. The child will do what mom says. So if the Taliban can't get rid of the mother, then they cannot rule. That's how important women are. Don't take mothering too lightly. We take it seriously. Whole regimes can change due to them. In South Florida women are more Americanized, they do religion, but go to school, have friends, etc. BUT we don't have double standards like Americans. We don't encourage boys to go out and have sex, and girls to not. Or visa versa. We hold boys to the same accountability.

Here Jacob gave a very interesting definition of Islam, for him it means "community and family." This is a very telling definition, which would make the IJEC crucial for the survival of Islam.

Finally, I asked him how he felt about fellow graduates potentially attending Sunni mosques in the future and his answer was different than Brad's. In fact he seemed slightly offended by the question. He was very frank in his belief that a Sunni mosque is very different from a Shi ite mosque, for him as different as a cathedral and a synagogue. He responded:

Hmm. I understand your question comes from a good place. But if you've studied our religion at all, we are TOTALLY different than Sunnis on practice. So a Shia wouldn't go there. The change is like going from a synagogue to a cathedral. But 
usually if they do, it's because they married a Sunni, but they are till Shia. But if they convert, that's fine. We are cool with Sunnis, a lot of us have Sunnis that are our best friends. We get along fine. But if someone converted, we don't mind. We showed then our stuff, if they didn't like it, it's not our fault. Let them live their lives, we don't push Shi'a Islam onto anyone. Shi'ism is a way of life. If they only learned even one thing, as simple as being good to others for example or thanking God for a meal, we're fine.

\section{Interview Analysis}

By and large there were variant voices reflecting a plethora of lived religious experiences, understandings, and desires throughout the interviews. One of the biggest issues that seemed to echo across most of these voices, volunteers and graduates alike, regarded the cultural influence at the IJEC. Many interviewees believed that there was notin fact any cultural influence on the education given at the education center. They actually cited other sources in the community that displayed cultural influence, including: the IJA general board, rituals, celebrations, dress, food, and the lectures by the imam. It was very odd to learn that they do not consider rituals part of Islamic education. As a participant observer I noted the cultural influences in all of the things they mentioned and definitely agree. However I also noted cultural influences in the education taught at the IJEC. The younger students were taught about the dharih room, which is particularly Pakistani. They are also taught prayers and style of lamentations for Muharram that are also particularly Pakistani. All of these teachings were both part of the education at the Sunday school and deeply influenced with Pakistani orthopraxy and belief. Therefore it is hard to understand why they do not regard these teachings as bearing a cultural influence on the education taught at the education center. The best hypothesis echoes to what they might consider true "Islam." 
It is simply crucial to understand that for the interviewees, Shi' ite Islam, is Islam, and the rituals that coincide with holidays, although done in a way that is particular to Pakistan, is also Islam. It is hard to distinguish the cultural elements inside a religion that is your own. However, a particularly Pakistani Shi ite understanding of Islam is taught at the Sunday school, even if the desired teaching is a culturally unbiased one. In fact mostly all of the interviewees seem to have the notion that culture and religion are two distinct worlds. They also understand the education at the IJEC as being as un-culturally biased as possible. The separation of religion and culturemay be a very legitimate and real concern in the minds of all teachers but to a participant observer the realization is different. The truth is an American Iranian or American Arab Shi ite child would simply just not learn about the dharih room or the taboot. They are also being taught different acts or prayers for specific holidays and a different style of lamentations for Muharram. There were a few interviewees that somewhat begrudgingly admitted to cultural influence at the education center: "There is some Indo-Pak influence in our education center, and yes it has to do with our culture." Another only implied the influence by saying: "Personally, I don't feel that culture influences the education center as much as it does IJA." Finally, another remarked: "At times I do feel that, but lately the administrative staff has tried to stay away from culture which is not part of religion."

The next big realization was the difference between the older and younger generations in acknowledging the role and presence of women at the IJEC. The younger generations of volunteers and graduates alike were quick to acknowledge and proudly proclaim the obvious strong presence of women at the center. In fact, it is strong indeed, 
most of the volunteers are women, most of the teachers are women, and most of the board at the IJEC has positions held by women. The youth echoed sentiments like: "As students we were surrounded by females especially because of the fact that most of the females that began the center and initially volunteered their time were mothers of most of the children."

The older generations on the other hand were more hesitant in acknowledging this situation however. It seemed as if the older generations almost tried to make excuses for the disparaging numbers, or lack of a strong male presence, by saying things like "in the beginning the IJEC had seen more male participants." Another said "many of our male peers work in the background."

Moreover, those who gave these answers seemed as if they were embarrassed by the fact that there was not an equal number of male participation. The cry of high female participation by the youth could simply be resulting from the fact that the younger generations are used to seeing women be active at all levels of society. One of the younger volunteers explained this precisely: "As more women are being educated and accepted in society today as well as the religion of Islam, I feel a strong acceptance and presence of women not only at IJEC but in the world generally." As a participant observer I did see a few men at the Sunday school but it was always heavily run by most of the women volunteers. In fact, on special celebrations held by the IJEC, like on Hussein day, the large number of men present in the community but consequently absent during the Sunday schooling process was even more notable. A strong male presence is seen on the general board of the IJA on the other hand. Since the beginning of the IJA, 
the general board was completely made up of males. It was not until this year that two positions as Chairs for the IJEC were occupied by women. Could this be a progressive step for the IJA? Perhaps, it depends on a person's definition of progressive.

On another note, it was fascinating to see how important all the interviewees found the IJEC. It seemed to be a place that definitely instilled the teachings of Islam, helped develop a strong Muslim identity, and kept this community united. So many examples were given to explain this interpretation. One interviewee said: "Any education center is an important aspect of a community, it keeps the community together, it gives the community a sense of belonging to a place that imparts knowledge." Another said: "The most important part of the IJEC is that it allows the students to identify with Islam, and not just the western, Anglo-culture." Another memorable quote is: "The center makes sure the next generation doesn't lose the right path of Islam." Another interviewee echoes the same priority concerning subsequent generations: "It helps build the future generation so they would not get lost." A graduate explains: "If Sunday school had not taught me Islam, I don't know if just my parents telling me to not do something would have worked..." Another graduate explains: "They helped me look into the deeper meaning of being a Muslim and how to see Islam as the right faith for me." Another graduate believes: "The education center definitely gave me more knowledge and material to learn from about Islam, even more than I would have been able to do own my own." Finally, another graduate recognizes how instrumental the education at the IJEC affected his understanding of himself as a person: "The education I received definitely led me to 
understand what and who I am as a person. It helped me compare other religious and educational information that I received throughout high school and college."

Finally, most interviewees across the board felt that the youth was struggling against or with Western cultural influences that might not be compatible with Islamic principles as taught through the IJEC. A lot of them seemed to think that the IJEC was in fact a place for the youth in the community to feel relief from this pressure. For some the IJEC allowed for a space where kids with Muslim values could identify with other children that share those same values. It seemed to give them a place for belonging as one interviewee put it. One interviewee felt that the IJEC was a way to keep the youth grounded in the face of a materialistic society. The youth also seemed to struggle with the negative portrayal and media attention that had been given to Islam inside of America. For some, the center provided a place where they could see and understand the peacefulness and true meaning of Islam.

\section{CHAPTER VI: CONCLUSIONS}

The experiences and voices of the American Shi' ite community need to be incorporated into the academic studies of the American Muslim community, as they are clearly present members of this community. The American Muslim community has been one of the latest integrating religious communities inside of the rich American landscape and especially in terms of religious education. However, the distinct histories, ethnicities, and denominations inside of the American Muslim community need to be explored and accounted for inside of academia. Liyakat Takim's first comprehensive American study on the American Shi' ite community should be acknowledged as a great development in 
American Muslim studies. In traditional Western understandings and studies of the "orient", Muslims served as the "other", with one monolithic understanding of what the "other" was. However, the American Muslim community is not monolithic and more studies need to be done to give a clearer picture reflecting all of these vast complexities. In fact, a comprehensive study of the Muslim women of the American Shi ite community remains to be done.

Moreover, the Muslim community is experiencing a lot of changes and struggles especially as world attention has increased due to terrorism. The internal Muslim community itself is struggling with the understanding and comprehension of the "real Islam" especially in light of the negative media attention and migration. Many of these immigrant Muslim families relocated to non-Muslim countries and the survival of their Islamic ideals is a deeply felt concern. The Muslim communities in the United States have reacted by making Islamic education available to the children of this community. The various forms of Islamic educations across the country have faced struggles and have developed differently depending on the particular communities'needs and goals.

Furthermore, the limited research that has been done on the growing American Islamic education shows that Muslim women are by and large the most involved in this education and at all levels. Although research like this is largely Sunni based, this study shows that the same type of Muslim women leadership and participation is reflected inside the Pakistani Shi ite community of South Florida. Women's participatory roles in American Islamic education, like the roles they play at the IJEC, need to be recognized as crucial for the identity of the different Islamic communities inside America. The essence 
of Islam might be one, but the identities are defined by those inside and outside of the community alike. The IJEC defines and educates a particular understanding of Islam and the center is what ultimately keeps this community and all their beliefs together and alive for the future generations.

Whether it is recognized or not a particular Pakistani Shi ite education is taught at the education center. The women seem to do it for their children, for the children of the community. Some see it as their obligation and others as a very fulfilling role. Students reflect on the huge impact it played on the person they became and why they now have such a great understanding of Islam. Many of the interviewees from this study believe this center is a place where students can identify with Islam. This has become an Islam that somehow is being carried over from what the older generations know to be Islam, as they had learned from their Shi' ite families back in Pakistan. These were the same Pakistani families that taught them the style of lamentations for Muharram and the proper way to decorate and show reverence for the Imams. These are the ways that the families, and in large part, the women, here in South Florida are teaching their children, namely as closely to how they were taught. This community is strengthened and sustained with much of the efforts stemming from the IJEC. The IJEC plays a central role in the sustaining of this complicated Pakistani Shi ite identity and women are at the heart of this operation.

Various issues and questions have arisen from this study that should to be explored. Muslim conception of culture and religion and the interrelationship this has played inside Islam is becoming a more pertinent issue, one which needsto be explored 
especially as communities relocate to other societies with completely different cultures. How much of Islam is culturally informed and how much is not? Other issues include: What awaits the future generations of Muslim Americans as they grow further and further apart from "home" cultural ties and experiences? How is the American Muslim education affecting the American Muslim community and its' identity? Consequently if Muslim women play such a big role in that education, how are Muslim women affecting the American Muslim identity? Will new types of Muslim identities be born? Could there ever be a unified American Shi itecommunity stripped of all the cultural ties as generations progress? How effective will the type of education, as taught at the IJEC be in the future American generations?

In conclusion, the academic studies of the American Muslim community need to reflect the various faces of Islam, including the Pakistani Shi ite communities. This study demonstrated that Pakistani Shi ite women of South Florida are playing active participatory roles inside of education. The women's participation at the IJEC mirror the same levels of participation that Muslim women in the American Islamic educational "system" as a whole are demonstrating. Ultimately, the IJEC plays a crucial rolefor the Pakistani Shi ite community of South Florida. As perceived by the women volunteers and graduates, the center is place where the children can identify with Islam and learn Islam as the Pakistani Shi ite community understands that "real" Islam. The IJEC strengthens and unifies this whole community alongside and sometimes in-spite of Western secular values. Finally, the IJEC contributes a great deal to developing and sustaining this double minorities' identity, and since women are primarily in charge of running it at all levels, it 
could be said that the Pakistani Shi ite women of South Florida are crucial in developing and sustaining the Pakistani Shi ite identity in South Florida. 


\section{BIBLIOGRAPHY}

Ahmed, Leila. Women and Gender in Islam: Historical Roots of Modern Debate. New Haven and London: Yale University Press, 1992.

Ahmed, Sapphire Mann. Experience Miracles; When Muslim Men and Women Work Together. Azizah. 3.2 (2004): 110-120.

Ali, Saleem H. Islam and Education: Conflict and Conformity in Pakistan's Madrassahs. Oxford and New York: Oxford University Press, 2009.

Anantharam, Anita. Engendering the Nation: Women, Islam, and Poetry in Pakistan. Journal of International Women's Studies. 11.1 (2009): 208-225.

Atkinson, Paul and Martin Hammersley. Ethnography: Principles in Practice. London and New York: Routledge, 1995.

Badran, Margot. Feminisms and Islamisms. Journal of Women's History. 10.4 (1999): 196-205.

Beal, Timothy K and William E. Deal.Theory for Religious Studies. New York, London: Routledge, 2004.

Cespedes, Geraldina. "Sources and Processes of the Production of Wisdom: An Approach from Intercultural Feminist Criticism." Feminist Intercultural Theology: Latina Explorations for a Just World. Ed. Maria Pilar Aquino and Maria Jose Rosado-Nunes. Maryknoll, New York: Orbis Books, 2007.

Chaban, Stephanie. Velvet Jihad: Muslim Women's Quiet Resistance to Islamic Fundamentalism.Journal of International Women's Studies. 11.1 (2009): 336-370.

Fernea, Elizabeth Warnock, and Basima Q. Bezirgan, eds. Middle Eastern Muslim Women Speak. Austin: University of Texas Press, 1977. 
Fine, Michelle and Selcuk R. Sirin. Muslim American Youth: Understanding Hyphenated Identities through Multiple Methods. New York and London: New York University Press, 2008.

Gardezi, Fauzia. Islam, Feminism, and the Women's Movement in Pakistan: 1981-91.Against All Odds. (1994): 51-61.

Ghadially, Rehana. Women's Vows, Roles and Household Ritual in a South Asian Muslim Sect.Asian Journal of Women's Studies. 4.2 (1998): 27-38.

GhaneaBassiri, Kambiz. A History of Islam in America. Cambridge: Cambridge University Press, 2010.

Haddad, Yvonne Y. and Jane I. Smith. "Introduction: The Challenge of Islamic Education in North America."Educating the Muslims of America. Ed. Yvonne Y. Haddad, Farid Senzai, and Jane I. Smith. New York: Oxford University Press, 2009.

Haddad, Yvonne Y. and Kathleen M. Moore, and Jane I. Smith.Muslim Women in America: The Challenge of Islamic Identity Today. Oxford University Press, 2006.

Halm, Heinz. Shi 'ism: Second Edition. New York: Columbia University Press, 2004.

Halm, Heinz. The Shiites: A Short History. Princeton. Markus Wiener Publishers, 2007.

Hanassab, S. "Caught between Two Cultures: Young Iranian Women in Los Angeles." In Irangeles: Iranians in Los Angeles, ed. Ron Kelley, Jonathan Friedlander, and Anita Colby, 223-229. Berkeley and Los Angeles: University of California Press, 1993.

Hegland, Mary Elaine. "Women of Karbala Moving to America: Shi'i Rituals in Iran, Pakistan, and California."The Women of Karbala: Ritual Performance and Symbolic Discourses in Modern Shi 'i Islam. Ed. Aghaie, Kamran Scot. Austin: University of Texas Press, 2005. 
Islamic Jaffaria Association, INC. 20 March.

$2011<\mathrm{http}: / /$ ijamiami.org/madressa_curr.html $>$.

Islamic Jaffaria Association, INC. 20 March.

$2011<\mathrm{http}: / /$ ijamiami.org/Policies_Procedure.pdf $>$.

Jamal, Amina.Feminist 'Selves' and Feminism's 'Others': Feminist Representations of Jamaat-e-Islami Women in Pakistan. FeministReview. (2005): 52-60.

Jamal, Amina. Gendered Islam and Modernity in the Nation-Space: Women's Modernism in the Jamaat-e-Islami of Pakistan.Feminist Review. (2009): 9-29.

Keyworth, Karen. "Islamic Schools of America: Data Based Profiles." Educating the Muslims of America. Ed. Yvonne Y. Haddad, FaridSenzai, and Jane I. Smith. New York: Oxford University Press, 2009.

Khan, Nadia Inji. "'Guide Us to the Straight Way': A Look at the Makers of 'Religiously Literate' Young Muslim Americans." Educating the Muslims of America. Ed. Yvonne Y. Haddad, Farid Senzai, and Jane I. Smith. New York: Oxford University Press, 2009.

Kourany, Janet A., Sterba, James P. and Tong, Rosemarie. Feminist Philosophies Second Edition. New Jersey: Prentice Hall, 1999.

Lootens, Tricia. Women \& Arab Society: Old Boundaries, New Frontiers. Off Our Backs. 26.7 (1986): 10-20.

Mernissi, Fatima. The Veil and the Male Elite: A Feminist Interpretation of Women's Rights in Islam. Cambridge, Massachusetts: Perseus Books, 1991.

Nadine Naber. Transnational Families Under Siege: Lebanese Shi 'a in Dearborn, Michigan, and the 2006 War on Lebanon. Journal of Middle East Women's Studies. 5.3 (2009): 145-177.

Nasr, Vali. 2006. The Shia Revival: How Conflicts within Islam Will Shape the 
Future. New York, London: W.W. Norton and Company.

Nyang, Sulayman S. "Convergence and Divergence in an Emergent Community: A Study of Challenges Facing U.S. Muslims."The Muslims of America. Ed. Yvonne Yazbeck Haddad. New York and Oxford: Oxford University Press, 1991.

Pandya, Sophia. Women's Shi 'i Ma'atim in Bahrain. Journal of Middle East Women's Studies. 6.2 (2010): 31-40.

Peach, Lucinda Joy. Women and World Religions. New Jersey: Prentice Hall, 2002.

Philbrick Yadav, Stacey. Segmented Publics and Islamist Women In Yemen: Rethinking Space and Activism. Journal of Middle East Women's Studies. 6.2 (2010): 1-32.

Reminick, Ronald A. Theory of Ethnicity: An Anthropologist's Perspective. Lanham, New York, and London: University Press of America, 1983.

Sachedina, Abdulaziz. "A Minority Within a Minority: The Case of the Shi'a in North America." Muslim Communities in North America. Ed. Yvonne Yazbeck Haddad and Jane Idelman Smith. Albany, New York: State University of New York Press, 1994.

Senzai, Farid. "The Outlook for Islamic Education in America." Educating the Muslims of America.Ed. Yvonne Y. Haddad, Farid Senzai, and Jane I. Smith. New York: Oxford University Press, 2009.

Shehrbano Zia, Afiya. The Reinvention of Feminism in Pakistan. Feminist Review. London: (2009): 29-47.

Takim, Liyakatail. Shi 'ism in America. New York and London: New York University Press, 2009.

The Islamic Schools League of America. 20 March. $2011<$ http://theisla.org/>. 
Thompson, Elizabeth. Public and Private in Middle Eastern Women's History. Journal of Women's History. 15.1 (2003): 52-65.

Worchel, Stephen. "A Developmental View of the Search for Group Identity." Social Identity: International Perspectives. Ed. Jean-Claude Deschamps, J. Francisco Morales, Dario Paez, and Stephen Worchel. London, Thousand Oaks, New Delhi: Sage Publications, 1998.

Zaman, Muhammad Qasim. "Tradition and Authority in Deobandi Madrasas of South Asia." Schooling Islam: The Culture and Politics of Modern Muslim Education. Ed. Robert W. Hefner and Muhammad Qasim Zaman. Princeton and Oxford: Princeton University Press, 2007. 


\section{APPENDIX B}

\section{IJEC FEMALE VOLUNTEER QUESTIONAIRE}

1. How long have you been volunteering for the education center?

2. What position do you hold and what do you typically do to prepare for you position?

3. What do you teach and what materials do you use for your class?

4. Why do you personally decide to volunteer your time and dedication to the education center?

5. Why is the education center important for the community?

6. Do you think the youth is struggling with American culture and influences?

7. What do you personally identify as?

8. Do you feel a strong female presence and participation at the education center?

9. Do you feel like the Pakistani/Indian culture influences the education center? If so, in what ways?

10. Do you feel the Pakistani/Indian culture affects the rituals and celebrations at IJA? If so, in what ways?

11. Why is the education center close to your heart? 


\section{APPENDIX C}

\section{IJEC GRADUATE QUESTIONNAIRE}

1. How long did you attend the education center and when did you graduate?

2. How do you feel the education you received affected your understanding of who you are and your identity?

3. How do you personally identify yourself?

4. Throughout the time span of the education you received at the center do you feel like there was a strong female presence and participation at the center? If so, in what ways?

5. How do you feel your life would have been different had you not attended the education center?

6. Do you feel your education gave you a stronger understanding of Islam?

7. How do you feel the center has affected the community?

8. Did you attend on a regular basis?

9. Do you feel the education was influenced by the Pakistani/Indian culture?

10. What did you enjoy the most from your experience at the education center?

11. Do you feel like the Pakistani/Indian culture affects the rituals and celebrations at IJA? If so, in what ways? 